Portland State University

PDXScholar

1978

\title{
A study to determine if service workers want additional training regarding Black issues
}

\author{
Patricia Dickerson \\ Portland State University \\ Diane S. Whalen \\ Portland State University
}

Follow this and additional works at: https://pdxscholar.library.pdx.edu/open_access_etds

Part of the Civic and Community Engagement Commons, and the Social Work Commons Let us know how access to this document benefits you.

\section{Recommended Citation}

Dickerson, Patricia and Whalen, Diane S., "A study to determine if service workers want additional training regarding Black issues" (1978). Dissertations and Theses. Paper 2681.

https://doi.org/10.15760/etd.2677

This Thesis is brought to you for free and open access. It has been accepted for inclusion in Dissertations and Theses by an authorized administrator of PDXScholar. Please contact us if we can make this document more accessible: pdxscholar@pdx.edu. 
A STUDY TO DETERMINE IF SERVICE WORKERS

WANT ADDITIONAL TRAINING REGARDING

BLACK ISSUES

by

PATRICIA DICKERSON

DIANE S. WHALEN

A practicum submitted in partial fulfillment of the requirements for the degree of

MASTER OF SOCIAL WORK

Portland State Iniversity

1978 
TO THE OFFICE OF GRADUATE STUDIES AND RESEARCH:

These advisors approve the research practicum of

Patricia Dickerson and Diane S. Whalen presented June 1, 1978

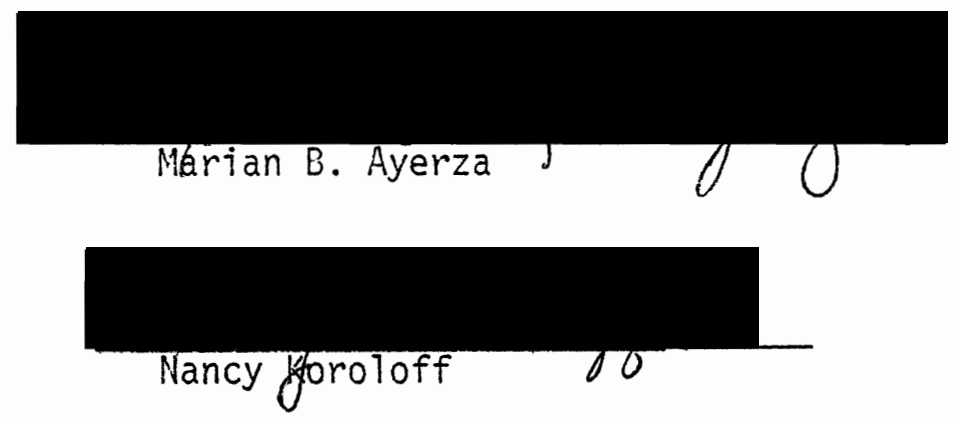




\section{ACKNOWLEDGEMENTS}

We wish to acknowledge and thank the administrators/directors of the agencies in the Albina area who granted us permission to use their agencies in our study. Our special thanks to the 31 respondents who participated in taking our survey and giving us needed information.

A special thanks to our advisors Marian B. Ayerza, Assistant Professor, School of Social Work, Portland State University, and Nancy Koroloff, Assistant Professor, School of Social Work, Portland State University, for their assistance, patience and critical reading of the numerous drafts of the manuscript.

We wish to thank each other for the support and patience we had with each other when things would not come together.

And finally, we wish to thank our husbands, Morgan and Bill, for without their understanding love this project would never have been completed.

p.d.

d.s.w. 
TABLE OF CONTENTS

PAGE

ACKNOWLEDGEMENTS .......................... i

LIST OF TABLES ......................... vi

CHAPTER

I INTRODUCTION ........................ 1

II REVIEW OF THE LITERATURE . . . . . . . . . . 4

RACISM ............. 4

Introduction

Institutional Racism

Cultural Racism

Racism in Portland

INTERVENTIONS ACROSS INTERRACIAL LINES . . . . 14

Introduction

Building Relationships with $\mathrm{Black} C \mathrm{Cl}$ ients

Assessment of Black Clients' Problems

Treatment

THE USE OF EDUCATION .......... 29

SUMMARY ................... 34

II RESEARCH DESIGN AND METHODOLOGY . . . . . 37

Choice of Area

Choice of Agencies and Sample

Instrument Development and Design

Instrument Administration 
CHAPTER

PAGE

IV DESCRIPTION OF FINDINGS .......... 41

V CONCLUSIONS AND IMPLICATIONS ........ 66

VI SUMMARY AND RECOMMENDATIONS . . . . . . 76

LIST OF FOOTNOTED REFERENCES . . . . . . . . . . . . . . 80

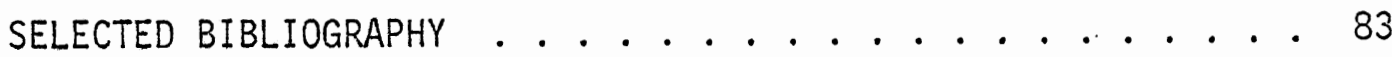
APPENDICES

I Questionnaire........... 89

II Introductory Letter to Service Workers . . . . . 98

II Table VII: Income Level of Respondents . . . . . 99 
I Age of Respondents ............ . 42

II Years Beyond High School ........... 43

III Education Beyond High School Completed by

Respondents ............. 43

IV Field or Major of the Respondents ........ 44

$\mathrm{V} \quad$ Size of Community Where Respondents Were Raised.............. 45

VI Geographical Area Where Respondents Were Raised .................

VII Income Level of Respondents (See Appendix) . . . .

VIII Number of Individuals to Whom Services Are Provided .................

IX Percentage of Individuals of Various Racial Groups to Whom Direct Services Are Provided

$X \quad$ Unit to Which the Majority of Direct Services Are Provided ...............

XI Number of Years Respondents Have Worked With Various Racial Groups ........... 50

XII Respondents' Job Satisfaction ........ 5I

XIII Black Life Experience - White Life Experience: Differences

XIV Present Treatment Modalities and the Needs of

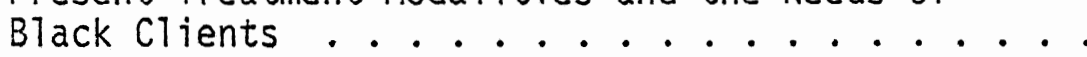

XV Service Workers' Awareness of Black Clients' Problems and Possible hays to Alleviate Those Problems ................. 
vij

TABLE

PAGE

XVI Service Worker's Needs and Further Training

Regarding Black Issues ........... 62

XVII Areas of Further Training Desired by Service

Workers .............. 64 


\section{CHAPTER I}

\section{INTRODUCTION}

During the 1960's a basic change occurred in the way American blacks saw themselves and in the way others saw them. Some blacks, who had worked for integration during the fifties, came to realize that they needed to adopt a separatist stance in order to maintain their identity as black people in a white society. For these blacks, then, the sixties became years of struggle for equal rights and equal opportunities. This struggle resulted in some changes. Legislation was passed to insure equality for blacks, programs were funded to help eradicate poverty in the cities, and Americans were made aware that blacks. were a people with a history, a culture, and a way of living that was different from that of the dominant group. It became popular to teach and to learn about black history and culture. This was evidenced by the many classes and workshops that were presented in schools, community centers and social service agencies throughout the country. Social workers, too, began to become more aware of the uniqueness of black clients and of the black community. This was documented in the social work literature.

If the sixties were days of protest and new beginnings, however, the seventies may be characterized by a "settling down" and a "settling in" attitude. Little is said anymore about black culture and biack pride. Some interpret this as an indication that blacks are satisfied. Others may know that this is not the case but may, nonetheless, choose to ignore black issues altogether. 
It is a concern of the researchers on this study that the issues of black culture and black uniqueness not be ignored in social service settings which serve black clients. Out of this concern arose the idea for this study.

The study is based upon five research questions which seek to determine service workers' perceptions of black life experiences, the causes of black clients' problems, and possible ways to alleviate these problems. Service workers are asked if present modes of intervention are effective in working with black clients. They are further asked if training regarding black issues would help facilitate their working with black clients, and if so, what areas of training would be most useful.

The researchers could have chosen any from among several client groups for this project. It was decided to limit the study to one group, however. Blacks were chosen because: 1.) the researchers have an interest in exploring the issue of racism. It is an assumption of the researchers that racism exists and that all non-white groups are affected by it. Blacks had the unique experience of being enslaved and colonized in the United States and it is believed that this history of enslavement exacerbated black people's experience of racism; 2.) blacks represent the largest racial minority group in Portland; and 3.) blacks have had more contact with the urban social service system than other racial minority groups and more literature is available regarding their contact with the system.

For the purpose of this study, "blacks" are defined as: peoples of color of African ancestry and "whites" are defined as non-colored peoples. 
In the literature review, a section is found which addresses interventions across interracial lines. The researchers are aware that the term intervention may be defined in many ways depending upon the philosophical framework which is employed. In this study, "intervention" is defined in terms of the treatment model proposed by Helen Harris Perlman. This model was chosen for the following reasons: 1.) Perlman's model is a traditional casework model and the researchers thought that it might be a familiar one to service workers; 2.) the model is simply broken down into three areas: relationship building, study-diagnosis and treatment; and 3.) the researchers are most familiar with this model. Although the researchers personally dislike the term "treatment" and the fact that it implies "illness" rather than "health" on the part of the client, this term will be used because it is consistent with Perlman's philosophical stance and terminology.

The body of this paper is composed of four sections. The literature review presents a general discussion and a brief historical overview of racism. Interventions across interracial lines and the use of education as a tool in lessening the effects of racism are also topics of the literature review. Following that section is a description of the research design and methodology of the study. Findings, conclusions and implications are discussed in the next chapters, and a summary and recommendations conclude the paper. 


\section{CHAPTER II}

\section{REVIEW OF THE LITERATURE}

\section{$\underline{\text { RACISM }}$}

\section{Introduction}

What is racism? It is an often misunderstood concept, one easily confused with discrimination and prejudice. Although racism is often used interchangeably with these other two terms, the meanings are distinct for each. To discriminate is "to make a distinction in favor of or against a person... on the basis of the group...to which the person... belongs, rather than according to actual merit." 1 When a club refuses to admit members of a certain ethnic group into its membership, this is an example of discrimination.

Prejudice is "an unfavorable opinion or feeling formed beforehand or without knowledge, thought, or reason. "2 Negative feelings or antagonism toward members of a group, a religion, or a race is prejudice. The feeling that these people are inferior is prejudice.

Racism is different than discrimination and prejudice. Stokely Carmichael and Charles $V$. Hamilton define racism as the "predication of decisions and policies on considerations of race for the purpose of subordinating a racial group and maintaining control over that group." 3

Racism is deeply woven into the fabric of American life. It is so widespread and ingrained in the values of this country that it seems invisible because it is so "normal". The fact that blacks are 
discriminated against in their attempt to obtain quality housing, education, employment, and medical care is only a part of the effect of racism. Just as devastating to black people is white America's denial of black culture, black history and indeed, black humanity. One of the strategies of racism is to convince blacks of white superiority and black inferiority. The white controlled media, white policemen and teachers, white absentee landiords and merchants are a11 viewed by blacks as the "white power" which keeps them oppressed. Black people are exposed daily to the white world of money and influence yet they often cannot partake of it because of their blackness. They know we11, from experience, that whites are in control of America and that blacks are powerless.

In the mid 1950's, under the leadership of Dr. Martin Luther King, blacks protested against racist policies and practices. In shouting "fredom now!", they demanded the opportunity to express themselves and to develop their potentialities. They demanded a "piece of the American pie". They wanted to be considered full citizens with full rights. The strategy these blacks chose was that of integration: an end to the separation of blacks and whites in America. Blacks wanted to become acculturated, to adopt the culture and values of another (the dominant) group, ${ }^{4}$ and so become accepted by that group. Other ethnic groups had become acculturated in the past; they had become a part of the American mainstream. Many of them were able finally to partake fully in American 1ife. Blacks wanted no less for themselves.

Black leaders knew that to effect this acculturation would take a 
tremendous amount of effort and risk because of the need to overcome such a long history of oppression and exploitation. The underlying philosophy of the civil rights movement recognized American society as basically good. This philosophy proposed the incorporation of black Americans into mainstream American life. This incorporation could both enrich the society as a whole and be a benefit to blacks who would finally be able to participate in the society as full citizens.

With this new spirit of determination and thirst for justice, then, the civil rights movement began. The struggle for civil rights was characterized by examples of personal courage. Some key incidents which eventually led to the passage of civil rights legislation are noteworthy. Rosa Parks refused to sit in the back of the bus in Montgomery, Alabama in 1955; four college students staged a sit in at a lunch counter where they had been refused service in 1955; the Freedom Riders came to Alabama in 1961; James Meridith defied school authorities and the governor of Mississippi in 1962. These and many other incidents culminated in a march on Washington led by Dr. Martin Luther King in 1963. Finally, comprehensive civil rights legislation was passed in congress.

It seemed that much had changed since the Supreme Court case, Plessy vs. Ferguson, in 1896. The ruling in that case had given sanction to separation of the races by stating: "If one race be inferior to the other socially, the constitution of the United States cannot put them on the same plane." It is true that the iynchings and the poll tax have been outlawed, racial slurs "nigger" and "boy" are not heard in public as often, and there are more blacks in politics and government. On the other hand, government statistics classify one third of American blacks 
as "poor", and quality housing is not obtainable by a large segment of the black population. Further, the ghettos still exist untouched, except for areas which were burned out in Watts, Newark, Detroit, and elsewhere in the mid-1960's.

Many white Americans do not recognize the poverty, the ghetto conditions, the oppression that exists for much of the black population today. It is probable that these white Americans see efforts as busing and affirmative action programs not as positive steps to equalize opportunities between blacks and whites, but rather as actions which grant special privilege to blacks solely on the basis of race. These whites then, may feel that they are victims of reverse discrimination. The many Americans who perceive the situation in this way tend to resent blacks and blame them for social problems that exist. These people also do not understand why blacks are not satisfied, now that they have "equal opportunities" due to civil rights legislation.

Many black people, too, are resentful. The unemployment rate is extremely high among blacks. This factor, along with many others, serves to keep many blacks out of the mainstream of economic life. In an economic system where materialism and the profit-motive are highly valued, and the acquisition of goods and services is paramount, money denotes power. It follows, then, that those who do not have money, the unemployed and the under-employed, also lack power.

So despite all the passion, the sacrifice, the martyrs, the rhetoric and the legislation, American blacks still forfeit their birthright in a racist society. 
Institutional Racism

Racism today is seen as a systernic and a systematic phenonemon. It is a part of the collective attitude of white Americans. Racism is so deeply ingrained in the fabric of American institutions that denying blacks first class citizenship and equal participation in the life of the society is just a matter of course. Conscious acts of racism are not required. Blacks are systematically deprived of opportunities in all areas of life: employment, education, housing, health, and so forth. 6

In order to better understand institutional racism, it is first necessary to know what institutions are and how they work. Institutions are "well established and structured patterns of behavior or of relationships that are accepted as a fundamental part of a culture". 7 Institutions give people a standardized and customary way to meet basic needs. Such needs include food, shelter, kinship, health care, and so forth. Institutions function through numerous satellite associations and organizations. These preserve social order and perpetuate the culture by accumulating and transmitting values, knowledge and skills.

Social institutions structure the way in which the major needs of the individual are met. Medical institutions, for instance, marshal the talents and resources of society so that health care can be provided. The health of all citizens is affected by general medical policies and by established practices and ethics. Public and private schools determine what knowledge will be transmitted to new generations, how it will be passed on and who will do the teaching. Legal and political institutions determine which laws regulate peoples' lives, how and by whom they 
are enforced and who will be prosecuted for which violations. 8

Social institutions, then, control a great amount of the social, cultural, and physical resources which are necessary in order for society to function. This results in these institutions having a great amount of power to reward or penalize. Among these rewards are good health, education, career or work opportunity, political influence, fair treatment by the law, security for self and family, decent housing and self respect.

There is no society which distributes its benefits equally. When race is used as a criterion for determining the distribution of social benefits, however, racism is present. The extent to which race determines this distribution is the extent to which institutional racism exists. Further, the extent to which a society permits institutional racism to exist is the extent to which it is a racist society. ${ }^{9}$

Carmichael and Hamilton state:

Racism is both overt and covert. It takes two closely related forms: individual whites acting against individual blacks and acts by the total white community against the total black community. We call these individual racism and institutional racism. The first consits of overt acts by individuals which cause death, injury, or the violent destruction of property. This type can be recorded by television cameras; it can frequently be observed in the process of commisssion. The second type is less overt, far more subtle, less identifiable in terms of specific individuals committing the acts. But it is no less destructive of human life. The second type originates in the operation of established and respected forces in the society, and thus receives far less public condemnation than the first type.

Thus, overt and individual racism takes place when a black family moves into a white neighborhood and is taunted and routed out. It is institutional racism which keeps blacks trapped in slum tenements and 
subject to exploitative slumlords, merchants, loan sharks and discriminatory real estate agents.

Institutional racism takes many different forms. Some are easily recognized, others are subtle. Segregation in schools and the exclusion of blacks from certain unions are easily identifiable forms of racism. The use of intelligence tests which assume white middle class values and experiences is a more subtle form of racism.

A devastating result of the subtlety of institutional racism in America is the pervasive attitude that blacks themselves are to blame for racial problems. In adopting this attitude, many whites, especially well meaning, well-educated, middle class whites, believe that it is the characteristics of blacks themselves which perpetrate racism. They believe, as the Moynihan report revealed, that "the fundamental problem (in the case of the black family) is that of family structure...Three centuries of injustice have brought about deep seated structural distortions in the life of the Negro American. At this point, the present tangle of pathology is capable of perpetuating itself without assistance from the white world". 11 While this may explain some immediate phenomena in black families, it is too simplistic. It does not take into consideration more fundamental determinants of the problems of black people in America.

William Ryan in his book Blaming the Victim explains how social workers and other professionals often look for the roots of problems within the victims of those problems -- and seem to have no difficulty locating the roots there. They believe that racism is perpetuated by dysfunctional black families who cannot pull themselves out of their 
"tangle of pathology" enough to enter the mainstream of American life. Ryan cites Andrew Billingsley who points out that those who accept the theory that the "Negro problem" is due to dysfunctional family structure have failed to consider two very basic concepts: racism and conflict.

The nature of institutional racism has already been briefly explored -- but what of conflict?

Ryan says that those who are concerned with the pathology of the black family "do not seem to perceive that an equalization of status will necessarily be accompanied by conflict". ${ }^{12}$ He asks, "Can we so easily avoid the basic issues of resources and power, status and hatred?" 13 Black leaders in the 1960's began to address these basic issues as they proposed the concept of "black power". Carmichael and Hamilton define black power as "a call for black people in this country to unite, to recognize their heritage, to build a sense of community...to define their own goals, to lead their own organizations and to support these organizations. It is a call to reject the racist institutions and values of this society. ${ }^{14}$

This concept of black power or black self-determination is based upon the strategy of separation rather than integration. Black power does not presuppose acculturation as the means to achieve the full fruits of citizenship. It is based not on a philosophy of consensus but rather on a philosophy of conflict. Black power recognizes the fact that if blacks want a share in the "American pie". they will have to demand it and wi1l probably have to wrest it from white America. This philosophy of conflict does not necessitate violence but neither does 
it deny its possibility.

\section{Cultural Racism}

A dimension of racism that is not often mentioned is cultural racism. A culture may be defined as racist to the degree that its values, ideas and beliefs include racial themes which reinforce individual and institutional racism. Racial stereotyping is a common form of cultural racism. The fact that stereotypes about certain ethnic and racial groups are widely accepted even in areas where these groups are absent attests to the fact that these stereotypes are not derived from personal experience but rather from the culture. In cultural racism, the world view that is transmitted during the socialization process includes racial themes. Individuals, therefore, are prepared to respond to minority group members in a particular way prior to any actual encounter with them. 15

\section{Racism in Portland}

Cultural racism was one of the factors that prepared the populace in Portland, Oregon for the influx of black workers during World War II. Prior to the war, there had been a few black families but their number was not significant. In fact, until they were repealed in 1926-1927, Oregon statutes forbade the settlement of blacks within state boundaries on an equal basis with whites. ${ }^{16}$

Kaiser shipyards recruited both black and white workers and the population for both groups in Portland began to grow. Housing became an immediate concern for black workers as the few blacks already in Portland were unable to provide housing for the many arriving blacks. 
Also, blacks were not allowed to rent many rooms which were available for whites only. Some alleviation of this problem occurred, however, with the development of Vanport, an area where low income housing was made available to both black and white workers. On May 30, 1948, the Columbia River broke through the dikes and Vanport was completely destroyed, leaving almost 5,000 blacks homeless. These people gradually relocated in the area in Northeast Portland referred to as Albina. ${ }^{17}$ Unemployment was not a problem for black men until the end of the war and the closing of the shipyards. When the shipyards began to close down, however, blacks were the first to be laid off because of lack of seniority and non-membership in the unions. Poverty followed unemployment. This marked the beginning of black hardships in Portland. In 1978 the picture is not much changed. In an article in the "Oregonian" on January 29, 1978, Alan K. Ota interviewed blacks in Northeast Portland who stated that, "black youth unemployment in Albina is higher (than the national average) perhaps about 50 percent". 18

Historically, then, blacks in Oregon have not been an integral part of the political, economic or educational life of the community. This was effected first through law, then through custom.

Furthermore, racist practices are so subtle in Oregon that both biacks and whites often deny their existence. On October 2, 1977, a local television public forum, "Town Hall", broadcast a program in which racism was discussed. It was interesting to note that while several minority persons agreed that racism was pervasive but subtle in Portland, others, especially the youth, questioned its existence in Portland at all. 19 
Anything less than clarity, honesty and forcefulness perpetuates the sliding over, dressing up and soothing down of true feelings, hopes and demands of blacks. Hypocritical smiles of blacks feigning contentment have misled whites into believing that racism in fact, does not exist or, if it does, it is no concern to the black population in Portland.

The Graduate School of Social Work at Portland State University seems to join others in Portland in denying the importance and the effects of racism. In the total social work curriculum there is onty one course dealing with the black family. Beyond this, there exists only the Northeast Portland Training Project. Commonly known as the "Albina Project"., the Northeast Portland Training Project places social work students in agencies in the Albina community for their field experience. Also, it should be noted that there is no minority recruitment program. It appears that preparing student interns to work with blacks is not a priority at the school of social work. One might question whether black culture is seen as not important enough to teach on the graduate level, or whether black clients are thought to be no different from white clients.

\section{INTERVENTIONS ACROSS INTERRACIAL LINES}

\section{Introduction}

In the researchers' professional academic experience, there has been little discussion of the issue of race in interventions with black clients. In response to this perceived lack, the researchers, themselves, decided to explore the issue. What follows has been gleaned 
from the literature.

The process of social casework, according to Helen Perlman, consists of three parts: relationship building, study-diagnosis and treatment. These three components are not mutually exclusive, nor do they necessarily occur in the order given. Before attempting diagnosis or treatment, however, some development of relationship is necessary. ${ }^{20}$

\section{Building Relationships with Black Clients}

Several authors have dealt with the obstacles to relationship building between blacks and whites. Gitterman and Schaeffer mention three of these obstacles: institutional racism, social distance and mutual unknownness. Petro and French, and Kibel point out a fourth obstacle: the fact that race is seldom acknowledged by either worker or client. A fifth obstacle is the fact that transference and countertransference may be hindrances to relationship building between blacks and whites. This issue is dealt with by Vontress, Petro and French, Cooper and Carter, and Haizlip. ${ }^{21}$ In order to explain how these factors can hinder relationship building across interracial lines, each "obstacle" will be dealt with separately.

Institutional racism is mentioned as a block to relationship building by Gitterman and Schaeffer. It has already been defined as that covert form of racism which "originates in the operation of established and respected forms in the community". 22

Burgest writes about racism in everyday speech and social work jargon. He illustrates how the English language equates blackness with evil and dirtiness. Examples are words such as biack sheep, black magic blacklist. He shows how social workers incorporate racism into their 
language with such terms as "cultural7y disadvantaged" and "economically deprived". He suggests that more honest terms might be "culturally dispossessed" and "economically exploited". 23

According to Petro and French, institutional racism is manifested in the negative self-image of blacks in America. Sotomayor agrees. She says that a person's self-concept becomes blurred when one's language, cultural patterns and ethnic experience are given negative connotations. $^{24}$ Solomon takes this one step further. She says that the other side of institutional racism is institutional powerlessness. This powerlessness produces stigma and negative valuation. ${ }^{25}$ for example, when certain services are available only for those who are "underprivileged", "culturally deprived" and "lower class", the acceptance of these services labels people as powerless and stigmatized.

The second obstacle in establishing relationships across interracial lines which is mentioned by Gitterman and Schaeffer, is social distance. Examples of factors in social distance are race, education, money, social position, power, authority and opportunities. Ethnicity, language and cultural differences also contribute to social distance. Sotomayor defines ethnicity as "cultural...uniqueness that allows for membership in a group...(a) sense of commonality of origin, beliefs, values, customs or practices of a specific group of people. ${ }^{26}$

Language helps to shape the world views which people hold. It helps to develop solidarity against an oppressive majority. In Black Jargon in White America, David Claerbaut explains how black dialects developed as a "defense against the oppression of an alien environment". 27 Black men and women altered white words and gave them more 
than one meaning so that a unique language, one not understood by the white oppressors, was developed. This development of a separate jargon has contributed to the distinct identity of blacks in this country. It represents a bond, a cohesiveness among black people that is not shared by whites. This bond, arising from the shared experience of oppression contributes to social distance.

The dictionary defines "culture" as "the sum total of ways of living built up by a group of human beings and transmitted from one generation to another". ${ }^{28}$ Sotomayor states that definitions of particular cultures are usually time bound and value laden and reflect the majority-minority relationship. Therefore, such terms as "cultural deprivation" arise. This implies that the white culture is seen as the standard of measure.

In attempting to understand social distance, then, ethnicity, language and culture must be considered as factors which separate blacks from whites in America.

The third obstacle to relationship building referred to by Gitterman and Schaeffer is mutual unknownness. They mean, for example, that neither blacks nor whites really understand each other. This mutual unknownness is due to several factors: 1) not being aware of racism within the society; 2) accepting myths and stereotypes; 3 ) having little contact between blacks and whites except superficial contact in stores, buses, on the street; and 4) defining cultural experiences of blacks as being inferior.

Mutual unknownness results in suspiciousness, fear, anger, pain, guilt, defensiveness, and guardedness. 
Another obstacle to relationship building is the fact that racial issues are seldom acknowledged by the worker in the treatment situation. Several authors point out that workers avoid the subject of race for several reasons. 29

Perhaps the most obvious reason workers avoid the issue of race is because of their discomfort with the issue. Stiles, et al., say that because workers are a part and a product of a racist society, they have incorporated negative stereotypes about blacks. To bring up racial issues forces workers to come to terms with their own prejudices. This can produce guilt and pain. By avoiding the issue altogether, then, some workers spare themselves this painful process of selfawareness.

Some workers avoid the issue of race in relationship building with black clients because they have been taught to be "colorblind". They have learned that "people are people", and that there are no differences between people of different groups. Burgest says that the purpose of this approach was to escape the "negative myths, stereotypes and assumptions" 30 workers had been taught about non-whites.

Finally, some workers avoid the issue of race because they fear unleashing strong feelings of anger in the client, especially in the case where the worker is white and the client is black.

Transference and countertransference are phenomena which occur in the treatment process. These phenomena are affected when client and worker are of different races.

Transference is an individual's reacting to a person (client re-acting to a worker) in a manner similar to the way he/she has reacted 
to someone in the past. These feelings can be either positive or negative. Vontress states that when the worker is white and the client black, these feelings are almost always negative.

Non-exploration of the issue of race can keep important information and feelings from being dealt with. This can be a considerable obstacle to transference which may be a necessary part of the treatment process.

Countertransference is a worker's reacting to a client the way he/she has reacted to someone in the past. In this case, the worker could see the black client in the same way he/she has observed other blacks in the past. The extent to which countertransference occurs may depend upon several factors. Some of these factors include: the racial background of the worker and the client, whether experiences in the past have been positive or negative and how many stereotypes the worker has incorporated into his/her belief system.

In order that countertransference not have a negative bearing on relationship building with black clients, workers must explore their own feelings about race so that clients will not be seen in stereotypical terms. Also, unless workers recognize and deal with strong feelings about race, they may not be able to listen to and empathize with clients. This could prevent workers from knowing their clients as individual persons.

One important aspect of the transference-countertransference issue which deserves mention is the aspect of white guift. Cooper explains that when emphasis in this country shifted from integration to selfdetermination for blacks, liberal whites who had fought hard for 
integration felt betrayed and abandoned. Suddenly, they were told that the struggle for equality was a struggle by blacks for blacks. They experienced frustration with wanting to help but not knowing how.

White workers learned to cope with this guilt in several ways: avoidance, not working with black clients; backlash, saying blacks have gone too far; overidentification, taking on behaviors, attitudes and feelings of oppression of blacks; and adoption of a "cripple psychology", seeing blacks only in terms of being victims. These all seem to be negative ways of coping. Cooper says that a more positive response to white guilt would be for white workers to alternate between compassion and resistance. In doing this, workers admit that relationships between blacks and whites are always changing. They acknowledge that the issues at stake are complex ones and that blacks will not gain power and authority until whites give it up. In alternating between compassion and resistance, then, workers make decisions regarding specific issues. Thus, on some issues, workers will be in agreement with blacks, and on other issues, with whites.

Although there are several obstacles to relationship building across interracial lines, the researchers maintain that these relationships can, in fact, be established.

The first step in relationship building is the acknowledgement that racism exists and that both clients and workers are deeply affected by it. Further, both clients and workers must admit that they have strong feelings regarding race. Workers need to know that "all blacks are angry" 37 and must deal with this strong emotion with their clients. Workers also must admit their own feelings and deal with them. 
Stiles, et al., state that verbal discussion of race between workers and clients is necessary if relationships are to develop. Several other authors agree.

Worker self-awareness is essential in building relationships because all of the worker's perceptions of the client will be filtered through that worker's own beliefs and attitudes. If these attitudes are not honestly dealt with, perceptions can be distorted. If relationships are to be developed, workers must want to work with black clients and must avoid manifestations of racism and prejudice.

Finally, in order to build relationships with black clients, Sager, Brayboy and Waxenburg state that workers must understand and accept the cultural patterns and lifestyles of their clients. They must recognize black clients' value systems as valid and not impose white values on them. 32

Cooper warns about going overboard in this area, however. She is concerned that workers see not only the clients' blackness but their "personness" as we11. The danger here is in seeing all blacks only in terms of being victims of racist oppression and all problems in this light without exploring the clients' personal hurts and ways of coping with them.

The establishment of trust is perhaps the most difficult aspect in relationship building with all clients. With black clients the issue of trust becomes even more complex. "Black people have learned to be distrustful." 33 It is this distrust that has helped them to survive in a hostile and oppressive society. Workers must respect this wariness then, as the coping mechanism that it is, and earn through work and actions, 
the trust that is necessary to relationship building.

\section{Assessment of Black Clients' Problems}

The second step in social casework according to Perlman is "study-diagnosis" or assessment of the client's problems. In discussing assessment and the psychosocial diagnosis, the importance of keeping the balance between "colorblindness" and ethnocentricity will be considered. Cooper defines ethnocentricity as the exaggeration of the importance or impact of racial factors. 34

Before workers can determine the problems of black clients, they must first come to terms with the client's "blackness". As has been mentioned previously, social workers in the past were taught to be "colorblind" in order to avoid negative stereotypes about blacks. 35 The researchers maintain that to be colorblind means to see the black client as white. In order not to fall into this pattern of thinking, workers must first admit that black clients are, indeed, black and that they are in some basic ways, different from clients who are white. In order to accomplish this, workers must consider what is involved for clients to be black in white America. To be black in white America means to be different from the stereotyped American. It means to be a colonial subject, dominated by the white power structure, politically, economically and socially. ${ }^{36}$

Black people in this country have grown up surrounded by negative images, images which tell them that to be black is to be inferior, culturally deprived, lower class. Even black families, themselves, transmit messages that to be black is to lack protection and privileges. 
"If you're black, get back" is first heard by many black children in their own homes or in the homes of other black children. These negative images not only contribute to the development of a negative self-image in black clients but often lead to anxieties about self-worth in these individuals. In order to make a psychosocial assessment of black clients' problems then, workers need to consider the impact of racism on these clients' lives.

Bertha Doremus developed a model for psychosocial assessment which takes into consideration four factors which are used to determine a client's psychosocial functioning. ${ }^{37}$ Those factors are roles, relationships, reactions and resources. ${ }^{38}$ with black clients, workers need to consider not only these four factors but also how they are perceived and acted upon in a racist society. A definition of roles, relationships, reactions and resources follows.

Role is the way in which persons act out the status they hold. A status can be ascribed, that is received, through no choice of ones own. For example, being female and black are statuses. Status can also be achieved, that is, earned or obtained through effort. Examples of achieved status are being married or being a student.

Roles often have to do with status within the family. Males in our society have been, traditional7y, breadwinners. Masculinity is bound up with earning money and with power -- especially the power to influence one's own life and the lives of others. Masculinity is also traditionally characterized by assertiveness and aggressiveness.

In the case of black males, they are often taught from earliest years that to be assertive and aggressive can only get them into trouble. 
They are denied jobs, as evidenced by their tremendously high unemployment rate, and thus, denied money and power. Even though the white society dictates that men take on the role of breadwinner, it is an oftentimes difficult role for black men to assume because they are denied employment.

Also, the welfare system as it exists, often encourages black men to leave their wives and children in order that the families might receive welfare grants. If a man remains at home and cannot find work, his wife and children may not be eligible for public assistance, and so may have no source of income.

Because of the exploitation of black men in American society, black women, too, have suffered. They have had to assume dual roles of mothering and breadwinning; they have heard their family labeled "dysfunctional" by sociological studies and the media; they have had to raise children to be passive, lest they be crushed by the racist society.

The roles of black men and women, then, must be seen in the context of a racist society. American society so often prevents blacks from attaining white standards of role behavior and then labels them "dysfunctional" and "deprived" when these standards are not attained.

A relationship refers to a series of interactions over time. When assessing clients' relationships in order to learn about their psychosocial functioning, workers are concerned with interactions with particular individuals, the content and quality of such interactions and the way in which clients perceive these interactions.

When considering the interpersonal relationships of black clients, a few facts must be taken into account. The black family is an extended kin- 
ship system which often incorporates those who are not actually tied to it by blood or marriage. Blacks often feel a solidarity with other blacks with whom they share history, culture and feelings of oppression. Andrew Billingsley calls this feeling of solidarity "a sense of peoplehood". ${ }^{39}$ Also, blacks are often wary of whites. They have learned this wariness in order to survive. These three factors may significantly influence the relational quality of black clients' personal lives. Reactions, as defined by Doremus, refers to how people react to their life situations. This has to do with the ways in which clients cope with stress in their lives. In reference to black clients, it must first be understood that stress is amplified because of lack of power in the social, political, and economic spheres of their lives. To further exacerbate this condition, black clients often have negative self-images forced upon them by the racist society. In order to deal with these stresses, blacks have developed their coping capacities to a high degree. Coping mechanisms used by many blacks include: denial of hurtful experiences; rationalization, that is, the belief that blacks are indeed deprived and dysfunctional; the tendency to overstrive to prove worth; manipulation of the system to achieve desired ends; and identification with the aggressor, the belief that "white is right" and black is inferior.

In looking at the clients' resources, several elements must be considered: finances, support persons such as family and friends, institutional resources, churches, clubs, neighborhood organizations, and personal resources such as intelligence.

Lack of money is often a problem for black clients. Unemployment 
and underemployment prevent blacks from participating in the "good life" as it is portrayed in the media. Television, in particular, focuses on the American dream which is perceived, by many blacks, to be unattainable. It is important for workers to understand and acknowledge the frustration and resentment of many black clients who see the attainment of material goods as a sign of success and worth and yet who are denied access to these material goods.

While black clients are often denied financial opportunities, their family and friends, churches and clubs, as well as personal resources, may serve them well in times of need. Too often these resources are ignored because workers assume that clients, whom they see as dysfunctional, would have dysfunctional support systems as we11.

Black clients' uniqueness regarding their "blackness" and "personness" needs to be acknowledged in order that therapeutic relationships may be developed. Cooper states that the recognition of black clients' ethnicity or "peoplehood" is important but she warns against ethnocentricity, that is, assessing clients' problems by looking solely at the external components. She says that workers must consider internal or psychologicol factors as well, in order to get a complete picture. She uses, as an example, a black child who displays disruptive and antisocial behavior. While this child's behavior might indeed be a normal response to an oppressive and racist society, seeing it only in this light does not take into account the ultimate cost to the child. "Confusing normal assertion with disabling aggression, stubbornness with independence or active motoric styles with hyperactivity does not help child patients. ${ }^{40}$ 
In summary, assessment of black clients' problems requires that workers take into account roles, relationships, reactions and resources. Workers must keep in mind that black clients' problems may be heightened because of the impact of racism but that their coping skills are likely to be well developed as these skills have been necessary for survival. Equaliy important in assessment is to view clients as fellow human beings with emotional and psychological needs as well as social, economic and political ones. It is in striking this delicate balance that workers are able to get a true picture of black clients and their needs.

\section{Treatment}

In discussing treatment, it is important to note that treatment "begins at the moment of encounter... How the caseworker acts...relates... draws out... the client's story and accompanying feelings... are a way of dealing with or 'treating' the other person. They affect (the client's) feelings, attitudes and actions from the first". 41 Both relationship building and assessment are part of the treatment process: clients judge whether workers are being helpful or not from the very beginning.

Treatment of black clients, if it is to go beyond the superficial level, will result in the client's overt expression of anger. Grier and Cobbs state that "all blacks are angry". If this is accepted as true, it follows that unless this anger is explored, treatment will be incomplete, at best. Stiles, et al., say that the expression of this anger is an appropriate response to the injustices clients have experienced. This expression instructs white workers about the black experience, and it tests the workers' ability to listen, understand and to deal with the painful experiences inflicted upon blacks because of racism. 
Often, workers are not able to deal appropriately with clients' painful experiences. Instead, because of the guilt they feel, workers, especially white workers, rely upon overcompensation to allay some of the pain. Overcompensation takes many forms, none of which contribute to a good therapeutic exchange. Vontress says that white workers may be overzealous and do more for black clients than for whites in order to atone for racial injustices; they may try to convince black clients that they are more trustworthy or noble than other whites the client has come in contact with; or they may be patronizing and oversimplify all the clients' problems as being due to race. Stiles, et al., prescribe a course of treatment for black clients. First they state that the negative self-image which is characteristic of so many blacks may be countered by the development of a new ego ideal. Because most ego ideals presented to blacks have been white and have embodied white values, they have served only to further denigrate the black person's self image. White workers may alter this ego ideal by representing new white values of respect and esteem for blacks and by acting upon these values in the treatment situation. White workers may also encourage black clients to choose respected blacks as ego ideals and invite them to identify with these new values and ideals. Black workers may themselves serve as ego ideals.

The second aspect of treatment involves helping clients to release hostile feelings which have resulted from painful experiences of racism. This aspect presupposes an openness and honesty in regard to expressing anger and hurt concerning racial experiences. This permission to ventilate feelings can free up energy for clients and help them 
to be more in control of their environments.

The third aspect of treatment which can be beneficial to black clients is the rechanneling of aggressiveness into assertiveness. Workers may help clients use their aggressive energy to battle oppressive social structures or to demand equal opportunities in education and employment. These are just a few specific aspects of treatment which may be explored with black clients.

For a more general treatise on treatment, Gitterman and Schaeffer offer a professional vision as a frame of reference in working with all clients. They maintain that to have a professional vision means that there is mutuality, a true give and take in the therapeutic relationship. The professional relationship is one in which two human beings come together to share thoughts and feelings and to learn from each other. The professional relationship should be based upon hope with a focus on achieving the highest potential possible for both the client and the worker. It should be a means whereby both client and worker become more open and thus; more human.

The researchers realize that this vision proposed by Gitterman and Schaeffer is indeed an ideal, a standard of perfection which may not be attainable in the "real world". They maintain, however, that ideals are to be striven for. If workers are content with mediocrity in their provision of services, these services will, at best, be mediocre.

\section{THE USE OF EDUCATION}

Several authors have written about the need of social workers to know more about the minority clients they serve. Longres, Turner, Gary, 
and Robertson speak to the need for changing curriculum in professional schools of social work to reflect the needs and concerns of minority clients. ${ }^{42}$ Petro and French, Lide, and Howley, on the other hand, treat education of workers through staff development within agencies. 43

Many topics have been suggested as important in learning about the black client.'s world. Turner says that workers need a basic knowledge of racism and a specialized knowledge regarding the way in which racial justice fits into the total picture of social justice. Gary states that workers should study the history and culture of the black community and understand its politics and economics. They should also understand how politics and economics are expressed through formal and informal institutions within the black community. He also stresses the need to develop new treatment modalities for working with black clients. Robertson speaks to some of these same issues. She also says that workers must look at blacks realistically and not through myths. Saunders says that workers must understand the ghetto: the importance of family, survival, and anger. She states that the primary goal of social work is not to change blacks but to help them to change their environment. ${ }^{44}$ These and other authors suggest that workers learn about black kinship patterns, role systems, communication networks, behavior and life styles. Workers should also know about language, recreation, black involvement with the "system" (schools, law, and so forth), and contributions of blacks in art, literature, music and science.

Perhaps a more important emphasis in education for work with black clients is the discovery, within workers, of their own attitudes and their agency's attitudes toward black clients. 
Pauline Lide in "Dialogue on Racism: A Prologue to Action" describes the process which staff persons in a family counseling agency went through in dealing with the topic of racism. She describes intellectualization as the first step in the process. Information on black history and culture was presented and rationally discussed. Workers did not explore feelings at that time. The second step included sharing of racial experiences among the black and white participants. Discussion remained on a somewhat superficial level but was more personalized. Eventually there was development of some trust between black and white staff members, and real sharing began. Workers began delving into their feelings of anger, resentment and guilt and admitting to their own racism.

As a result of this process, some self-awareness was gained, as well as the knowledge of the feelings of co-workers and a better appreciation of the meaning of racism. Many of the feelings of guilt, frustration and hopelessness were unresolved however, as this phase of the staff education process came to an end. Because there were so many unresolved feelings, an intensive two day workshop was held.

John M. Howley, Jr., the unit director for the family counseling center described in Lide's article, wrote an article on the effects of this two day follow-up workshop on racism. This workshop was held at the culmination of the two year inservice process described by Lide. During this workshop, the process of intellectualization and rationalization followed by a struggle with feelings occurred again. During the workshop, staff persons discovered that they were being challenged to change their thinking about blacks. This was a struggle for workers 
because it forced them to confront the racism within themselves. The group finally came to terms with the fact that "racism was the major reason for the inability to work with black families". 45

In recognizing the racism in themselves, the staff group decided that this was a common problem for all other workers in the agency. From there they discovered ways in which their agency really was set up to serve the white population and how it, in fact, reinforced institutional racism. This group also decided that in order to change the status quo, peer support among staff would be essential. This having been established, the staff should explore and come to a better understanding of the meaning of institutional racism. They could then create a model of an agency which would be responsive to the needs of the total community. This having been accomplished, the staff could then identify changes in the family counseling agency's program and staff development which would be necessary to effect the desired model.

The major change in the focus of this staff group seems to have been from "'Let's examine what makes a black person tick', to 'Let's examine what's going on within ourselves in the struggle on racism'". ${ }^{46}$ A staff person in writing his reflections of this process said, "We know where we are. We are not pretending all the time now. We are facing our problems slowly and making changes slowly, but at least we know what our problem is". 47

Other authors who have proposed exploration of feelings about racial issues have described various results of this process. Tidwell says that a result will be the realization that conflict is necessary to societal change. ${ }^{48}$. Gitterman and Schaeffer state that exploring 
these issues will result in feelings of suspiciousness and fear, anger, pain, defensiveness and guardedness. They maintain, however, that without this experience, no honest communication between blacks and whites will take place. Sager et a1., point out that when workers explore racial issues, they may come to realize that it is not the client who is dysfunctional but it may be that therapeutic measures designed to work with middle class whites are not appropriate for black clients. This challenges workers to listen to their clients and to be creative.

As a final note on the use of education in lessening the effects of racism, the researchers will put education in perspective. They would like to propose what education can and cannot do.

Barbara Shannon says "institutional racism wi11 not disappear until individuals change". 49 This implies that education of individual workers is crucial to societal change. Petro and French state that education through staff development can sensitize workers to the forms of racism so that they can develop strategies to halt its transmission. 50

On the other hand, John Longres states that racism is pervasive, subtle, institutionalized. Much of our black population shows the effects of a history of racism. These people are poor, undereducated, unemployed and angry. This problem may not be solved within the system because it is this very system which sanctions and gives authority to racist practices. In order to accomplish real change, then, the rules must be changed; that is, societal change must occur. Longres says that education can be a part, but that education alone, will not change the character of society.

Sager, et al., agree with Longres that education is not an answer 
in itself. They do propose, however, that the education of workers is one way to help alleviate some of the pain of individual clients.

The writers conclude from the literature then, that although authors differ in their opinions as to how effective education may be in overcoming racism, they do believe that it is a valid method for enabling the reduction of racist attitudes.

\section{SUMMARY}

In writing this chapter, the attempt is to discuss three main topics: racism, interventions across interracial lines and the use of education as a tool in lessening the effects of racism.

First, a discussion of racism is presented which highlights, in particular, the subjects of institutional racism and the history of racism in Portland.

Interventions across interracial lines is the second major topic of the literature review. Interventions are discussed according to a three phase model: relationship building, study-diagnosis and treatment.

Five obstacles to relationship building are delineated. They are: 1.) institutional racism, 2.) social distance, 3.) mutual unknownness, 4.) the fact that race is seldom acknowledged in the treatment process, and 5.) the ways in which transference and countertransference can be hindrances to treatment.

Despite the obstacles to building relationships.across interracial lines, several authors maintain that these relationships can be established. These authors state that workers may facilitate building relationships with black clients by: 1.) acknowledging the fact of race 
on the part of both workers and clients, especially through verbal discussion of racial issues, 2.) accepting and understanding black clients' cultural patterns, lifestyles and values, 3.) maintaining the balance between clients' blackness and their personness and 4.) accepting the wariness of black clients and working to earn their trust.

The discussion of the study-diagnosis phase of intervention across interracial lines focuses upon acknowledging clients' blackness and how workers should assess clients' roles, relationships, reactions and resources in light of their uniqueness as blacks.

According to the literature review, treatment of black clients could include: assisting black clients in developing a new ego ideal, helping clients to ventilate hostile feelings and rechanneling clients' aggressiveness into assertiveness. A general treatise on treatment calls for a professional vision in which clients and workers strive for mutuality in the therapeutic relationship.

The third major topic in the literature review is the role of education as a tool in lessening the effects of racism. Education can occur in many contexts. Those discussed in this study include education within professional schools of social work and inservice education in social agencies.

Two areas are emphasized in the discussion of education: first, knowledge of the black client's world, and second, self-awareness within workers regarding racial issues and the experience of feelings which, then, accompanies awareness of these issues.

This discussion of racism, interventions across interracial lines and the use of education in lessening the effects of racism, serves as 
an introduction to the researchers' study. In this study, service workers are asked questions which may cause them to think about racism and its effects on black clients' lives. The questionnaire asks workers how they feel about the effectiveness of present modes of intervention which are employed with black clients. It asks them if further education regarding black issues would facilitate their working with black clients and attempts to find out which areas of education would be most beneficial to them.

The following chapter of this paper describes the researchers' methodology and design of the study. 
CHAPTER III

RESEARCH. DESIGN AND METHODOLOGY

In the researchers' contacts with service workers in the Albina community, the question arose as to whether these service workers needed additional training in the area of black culture, history, language patterns, and life styles. It was also questioned whether additional training would facilitate their working with their black clients. In order to obtain the desired information, it was decided that a survey would be the primary method used. By means of the survey, the researchers also hoped to determine which areas of training would be most useful to these service workers.

In order to administer this survey, the following steps were utilized: (1) the area was chosen, (2) the agencies and respondents were selected, (3) the instrument was developed and designed, and (4) the instrument was administered. Each of these four steps will be discussed separately in the following sections.

\section{Choice of Area}

The area in which the researchers chose to administer the survey is known as Albina. This area is located in Northeast Portland. Albina is defined geographically as the area west of 21 st Avenue, east of Interstate-5, south of Portland Boulevard and north of Fremont Street. This area outline corresponds to the Mode 1 Cities boundaries. The Albina area was chosen because it is the area where the largest concentration of 
blacks resides in Portland.

\section{Choice of Agencies and Sample}

Within the Albina area are located 12 service agencies whose workers provide counseling and/or therapy to clients. For the purpose of this study, the researchers limited the agencies to those providing counseling and/or therapy. This counseling and/or therapy may take the form of individual, group or family work and deal with areas such as life stresses, substance abuse, and communication problems. Those persons providing this type of counseling and/or therapy will be referred to as service workers.

The researchers sent letters requesting appointments with the director/administrator of each agency to explain the survey and its focus. In some agencies, the director/administrator asked supervisors to inform the service workers that they would be contacted by the researchers. In other agencies, the director/administrator informed the service workers directly.

The researchers were granted permission to administer the survey in 9 of the 12 agencies. A 50\% random sample of workers in these agencies was taken.

\section{Instrument Development and Design}

The focus of the pilot study was attitudinal: that is, the researchers wanted to determine attitudes which workers held about their black clients. Finding that they were too biased themselves to sensitivity ask attitudinal questions, however, the researchers decided to 
do a needs assessment. The researchers feit that they could be more objective in asking questions regarding training needs than they could be in trying to determine attitudes of service workers.

In administering the pilot survey during July 1977 to a sample of 10 people, who were mainly service workers, mixed reactions were obtained. Several people believed that the researchers were trying to trick them, and that there was a hidden agenda behind the survey.

The scale response included four categories, "strongly agree", "agree", "disagree", and "strongly disagree". Many workers felt that the researchers should have had a Likert scale complete with a category labeled "no opinion" so that people would not be forced to answer difficult questions. There were also feelings that some of the questions were ambiguous. Finally, most felt that the survey was too long.

The final instrument was composed of: a cover letter, fourteen demographic questions, and the main body of the survey, which consisted of 29 questions. The purpose of the cover letter was to explain who the researchers were. (See appendix for copy of the letter.)

Twenty-eight of the questions in the main part of the survey were answered on a Likert scale. This Likert scale consisted of: one, representing "strongly agree"; two, "agree"; three, "disagree"; and four, "strongly disagree".

The final question was openended. Those taking the survey were asked: "which areas of training (if any) related to more effective service delivery to the black client would you find most beneficial?" 


\section{Instrument Administration}

As their universe of study, the researchers selected all those agencies within the geographic area chosen, which provide counseling and/or therapy to its clients. There were 12 such agencies. Of these 12 agencies, 9. granted permission for the survey to be taken. Three agencies declined for the following reasons: (1) no response from the director/administrator, (2) service workers uninterested, and (3) administrative problems within the agency.

A $50 \%$ random sample of the service workers from each of the 9 agencies was taken. This $50 \%$ random sample represented 50 service workers, so that 50 questionnaires were distributed.

The questionnaires were left at the 9 agencies in November, 1977. The researchers left the questionnaires with the receptionist at each agency. The receptionist saw that the identified service workers received the questionnaire. These service workers, after completing the questionnaire, returned it in a sealed envelope to the receptionist. This procedure was followed in order to insure confidentiality. The service workers were also requested not to put their names on the questionnaires.

Follow-up on questionnaires not returned was done verbally by the receptionist in some agencies. In other cases, the researchers sent notes and made telephone calls as reminders.

Fo the 50 questionnaires distributed, the researchers had a return rate of $62 \%$, or 31 questionnaires. 
CHAPTER IV

\section{DESCRIPTION OF FINDINGS}

The main focus of this section is to provide a facutal description of the data obtained from the survey. For purposes of clarity, the researchers have chosen to comment on specific data that represents data from the highest and lowest percentiles. The following tables present data collected from the 31 respondents to the survey.

\section{$\frac{\text { Selected Characteristics of Sample }}{\text { (Sex-Race-Age) }}$}

The demographic data shows that of the 31 respondents, $71 \%$ (22) are female and 29\% (9) are male. Seventy-four percent, (23) of the 31 service workers are white, and $26 \%$ (8) are black. The mean age of the respondents is 36.5 years, with a range from 24 to 57 years. Fiftyfive percent (17) of the service workers are between the ages of 24 and 35 while $19 \%$ (6) of the workers, are age 46 or over. 
TABLE I

AGE OF RESPONDENTS

\begin{tabular}{lcc}
\hline & & \\
\hline Category & Frequency & Percentage \\
\hline $24-29$ & 9 & $29 \%$ \\
\hline $30-35$ & 8 & $26 \%$ \\
\hline $36-40$ & 1 & $3 \%$ \\
\hline $47-45$ & 7 & $23 \%$ \\
\hline $46-50$ & 4 & $13 \%$ \\
\hline 57 and over & 2 & $6 \%$ \\
\hline TOTAL & 31 & $100 \%$ \\
\hline
\end{tabular}

Selected Characteristics of the Sample (Education)

Ninety-three percent, (29) of the 31 respondents have completed 0 10 years of education beyond high school. Another $6 \%$ (2) have completed 11 to 15 years of additional education. In Table III, it is shown that $32 \%$ (10) of the respondents have a Bachelor of Arts or Bachelor of Science degree and $42 \%$ (13) have their Masters in Social Work. Sixteen percent, (5) of the respondents have masters in areas other than social work.

of the service workers who responded regarding their field or major while in college, $87 \%$ (27) majored in social science. Under the category "other", 13\% (4) majored in such areas as history, language, occupational therapy, and so forth. (Table IV) 
TABLE II

YEARS BEYOND HIGH SCHOOL

\begin{tabular}{lcc}
\hline \hline Category & Frequency & Percentage \\
\hline $0-5$ & 15 & $48 \%$ \\
\hline $6-10$ & 14 & $46 \%$ \\
\hline $11-15$ & 2 & $6 \%$ \\
\hline TOTAL & 31 & $100 \%$ \\
\hline \hline
\end{tabular}

TABLE III

EDUCATION BEYOND HIGH SCHOOL COMPLETED BY RESPONDENTS

\begin{tabular}{lcc}
\hline Degrees & Frequency & Percentage \\
\hline Bachelor of Arts or Bachelor of Science & 10 & $32 \%$ \\
\hline Master of Social Work & 13 & $42 \%$ \\
\hline Other Masters & 5 & $16 \%$ \\
\hline Other* & 3 & $10 \%$ \\
\hline TOTAL & 37 & $100 \%$ \\
\hline
\end{tabular}

*The "Other" category refers to education received beyond the Master's level in any field. 
TABLE IV

FIELD OR MAJOR OF THE RESPONDENTS

Field or Major

Frequency

Percentage

Social Science

27

$87 \%$

Other

4

$13 \%$

TOTAL

31

$100 \%$

Selected Characteristics of Sample

(Geographical Area and Size of Community Where

Respondents Raised and Income Level of Respondents).

Table $V$ shows that $29 \%$ (9) of the respondents were raised in communities with populations of 15,000 and under. This is interesting in that these service workers work in the Albina area in the city of Portland which has a population of more than 320,000 . The researchers found that $39 \%$ or 12 workers, came from communities with population comparable in size to that of Portland and only 6\% (2) of the workers, came from communities with populations of 50,000 to 100,000 .

Service workers were asked in what geographic area they were raised. They were asked to check North, South, East, or West. The researchers did not take into consideration that people define geographical areas differently; therefore, they had some difficulty in interpreting the responses. For example, some responses received included: Canada, Midwest, and so forth.

Forty-eight percent or 15 of the service workers, came from what they considered the West. Twenty-eight percent (8) came from the East. The South and North each had 13\%, (4) service workers who said they were 
raised in that area.

The researchers asked workers to report their annual income levels. Judging from respondents' comments, there was ambiguity as to whether individual or family income was to be reported. Because this was unclear, the researchers feel that in include the table regarding income in this chapter would be misleading to the reader. For this reason, Table VII, Income Level of Respondents, is found in the appendix.

\section{TABLE $V$}

SIZE OF COMMUNITY WHERE RESPONDENTS WERE RAISED

\section{Community size}

(population)

Frequency

Percentage

\begin{tabular}{lcc}
15,000 and under & 9 & $29 \%$ \\
\hline 15,000 to 50,000 & 4 & $13 \%$ \\
\hline 50,000 to 100,000 & 2 & $6 \%$ \\
\hline 100,000 to 500,000 & 12 & $39 \%$ \\
\hline 500,000 and over & 4 & $13 \%$ \\
\hline TOTAL & 31 & $100 \%$ \\
\hline
\end{tabular}


TABLE VI

GEOGRAPHICAL AREA WHERE RESPONDENTS WERE RAISED

\begin{tabular}{lcc}
\hline \hline Category & Frequency & Percentage \\
\hline West & 15 & $48 \%$ \\
\hline East & 8 & $26 \%$ \\
\hline South & 4 & $13 \%$ \\
\hline North & 4 & $13 \%$ \\
\hline TOTAL & 37 & $100 \%$ \\
\hline \hline
\end{tabular}

Selected Characteristics of Service Workers' Caseload

Service workers were asked to estimate how many individuals to whom they provide services. Fifty-five percent of the respondents estimated that they provide services to 1-49 individuals during the year. Thirteen percent of the workers provide services to 100-199 individuals, while $10 \%$ provide services to 200 persons and over.

The researchers asked the service workers what percentage of their caseload is comprised of blacks, whites, and others. The responses were interesting. Thirty-nine percent of the workers say that $26 \%-50 \%$ of their caseload is black. Thirty-two percent of the service workers say that $51 \%-75 \%$ of their caseload is made up of white clients and $77 \%$ of the service workers say that $1 \%-25 \%$ of their caseload consists of others.

Considering that these service workers provide services in the Albina area, which has the largest concentration of blacks in Portland, the researchers expected the percentage for blacks on caseloads to be in 
the $51 \%-75 \%$ percentile, if not higher. Taking all this into consideration, it appears that white clients make up the largest group on caseloads of the 31 respondents in the survey.

Forty-eight percent of the service workers provide the major part of their direct service to individuals and $28 \%$ say that they provide the majority of their services to families. Thirteen percent of the workers provide services primarily to groups or others who were not specified.

\section{TABLE VIII}

NUMBER OF INDIVIDUALS, TO WHOM SERVICES ARE PROVIDED

\begin{tabular}{lcc}
\hline \hline Category & Frequency & Percentage \\
\hline No response & 2 & $6 \%$ \\
\hline $1-49$ & 17 & $55 \%$ \\
\hline $50-99$ & 5 & $16 \%$ \\
\hline $100-199$ & 4 & $13 \%$ \\
\hline 200 and over & 3 & $10 \%$ \\
\hline TOTAL & 31 & $100 \%$ \\
\hline \hline
\end{tabular}




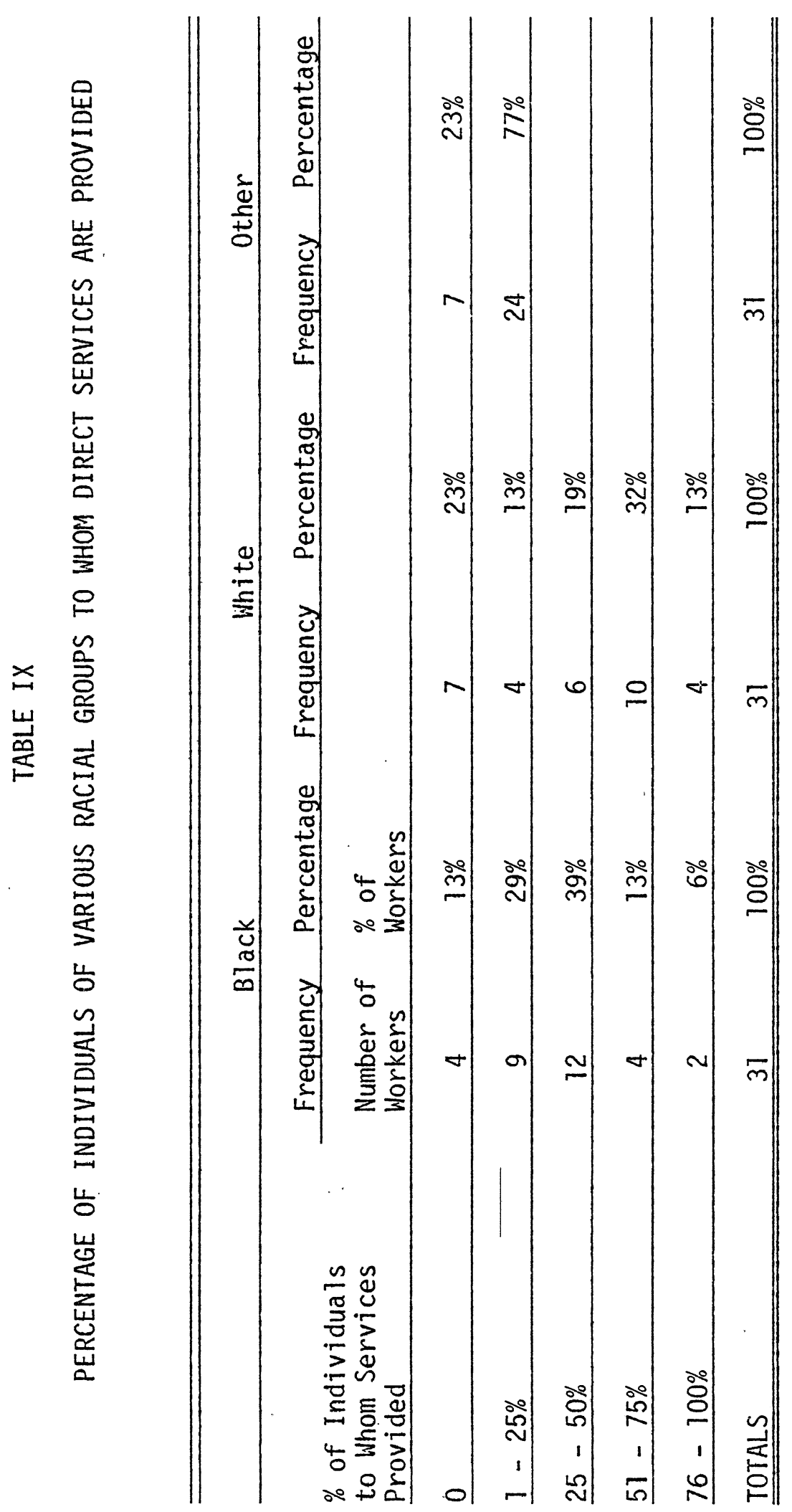


TABLE X

UNIT TO WHICH THE MAJORITY OF DIRECT SERVICES ARE PROVIDED

\begin{tabular}{lcc}
\hline Category & Frequency & Percentage \\
\hline No response & 3 & $10 \%$ \\
\hline Families & 9 & $28 \%$ \\
\hline Individuals & 15 & $48 \%$ \\
\hline Groups & 3 & $10 \%$ \\
\hline Other & 1 & $3 \%$ \\
\hline TOTAL & 31 & $100 \%$ \\
\hline
\end{tabular}

Number of Years Working with Various

Racial Groups and Job Satisfaction.

Forty-five percent of the service workers, have worked 1 to 5 years with black clients, $48 \%$ have worked 1 to 5 years with white clients, and $36 \%$ have worked with other ethnic groups from 1 to 5 years. Six percent of the service workers have worked with black clients for 21 years and over, $3 \%$ with white clients for 21 years and over, and $3 \%$ with other ethnic groups for 21 years and over.

The 31 respondents were asked if they are satisfied with their job. Ninety percent say that they are satisfied. Low satisfaction is expressed by $6 \%$ of the workers. 


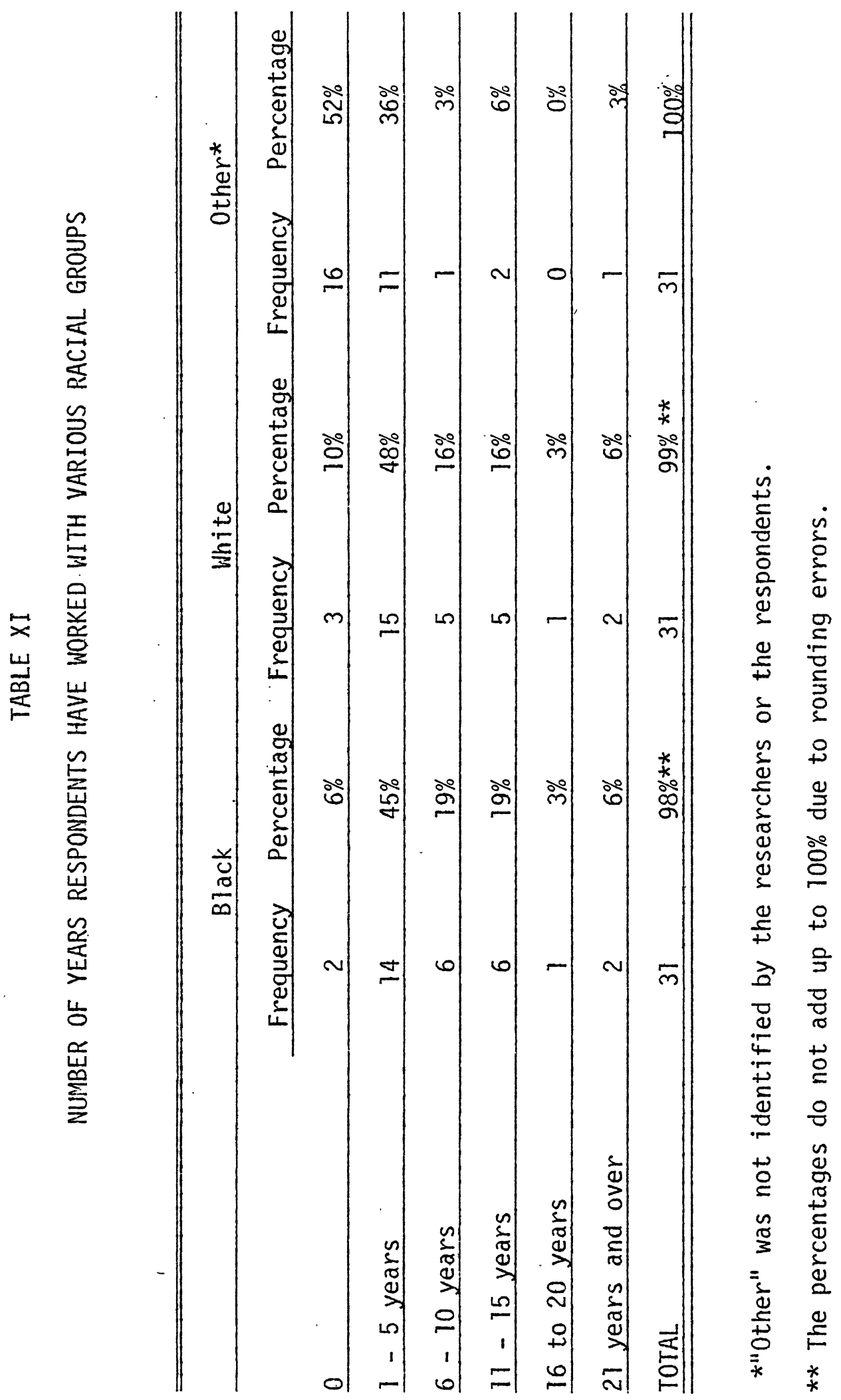


TABLE XII

\section{RESPONDENTS' JOB SATISFACTION}

\begin{tabular}{lcc} 
Category & Frequency & Percentage \\
\hline No response & 1 & $3 \%$ \\
\hline High & 14 & $45 \%$ \\
\hline Medium & 14 & $45 \%$ \\
\hline Low & 2 & $6 \%$ \\
\hline TOTAL & 31 & $99 \%$ \\
\hline
\end{tabular}

*Precentages do not add up to $100 \%$ due to rounding error.

Responses to Items on Questionnaire

In Table XIII, item 1, 68\% of the service workers generally agree that the black family is a strong unit within society. Of this $68 \%$, $16 \%$ strongly agree. Six percent of the respondents strongly disagree with this statement in item 1. When asked if the family is seen as a strong unit within society in item 13 , Table XIII, $71 \%$ of the respondents agree that it is a strong unit.

In item 7, Table XIII, the question is asked if black family life differs from white family life. Fifty-one percent of the service workers agree with this statement. Thirty-nine percent of the workers disagree that black family life differs from white family life, and $10 \%$ did not respond to item 7 .

Eighty-one percent of the respondents to item 5, Table XIV, disagree that the role of the service worker is to help blacks become 
assimilated into the dominant culture. Twenty-six percent of the respondents strongly disagree with this statement. In Table XIV, item 27 , the question is asked if the role of the service worker is to help blacks become acculturated to the dominant culture. Of those responding, $90 \%$ disagree and within this $90 \%$, $16 \%$ strongly disagree.

In item 18, Table XIV, $64 \%$ of the service workers agree that interventions they use with black clients are usually geared to help them cope with (adapt to) their life situation.

In Table XIV, item 14, service workers general1y agree (61\%) that they would help their clients if they, the service workers, involved themselves politically. Thirty-two percent disagree with this statement. In responding to item 15, Table XIV, however, $65 \%$ disagree that service workers do involve themselves politically.

In item 11, Table XIV, service workers are almost eveniy divided as to whether traditional counseling methods are effective in working with white clients. Forty-eight percent agree and $42 \%$ disagree with this statement. In item 12, Table XIV, $61 \%$ of the respondents say that traditional methods are not effective in working with black clients.

When service workers were asked, in item 19, Table XIV, if they feel that the current system of service delivery meets the needs of most black clients, $90 \%$ of the workers say that it does not meet these needs. Nineteen percent strongly disagree that needs of blacks are being met under the current system. Most (84\%) of the respondents feel that new methods of intervention are needed in working with black clients. Sixteen percent strongly agree and $10 \%$ disagree with item 28 , Table XIV. 
In responding to item 16, Table XIV, $83 \%$ of the workers agree that the community has a general distrust of service workers.

Self-awareness is essential to good service delivery according to $97 \%$ of the respondents to item 6 , Table XIV. 


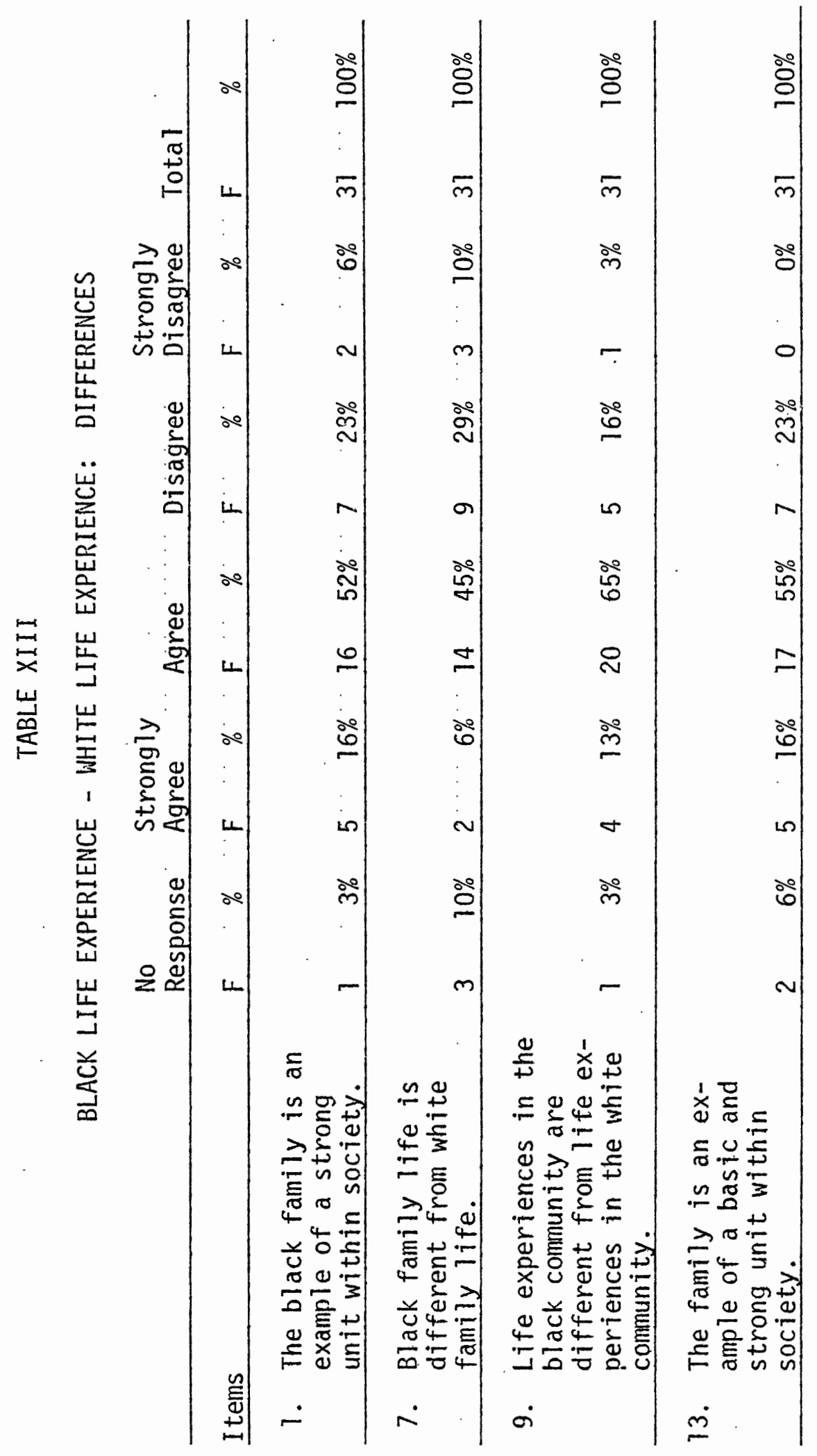




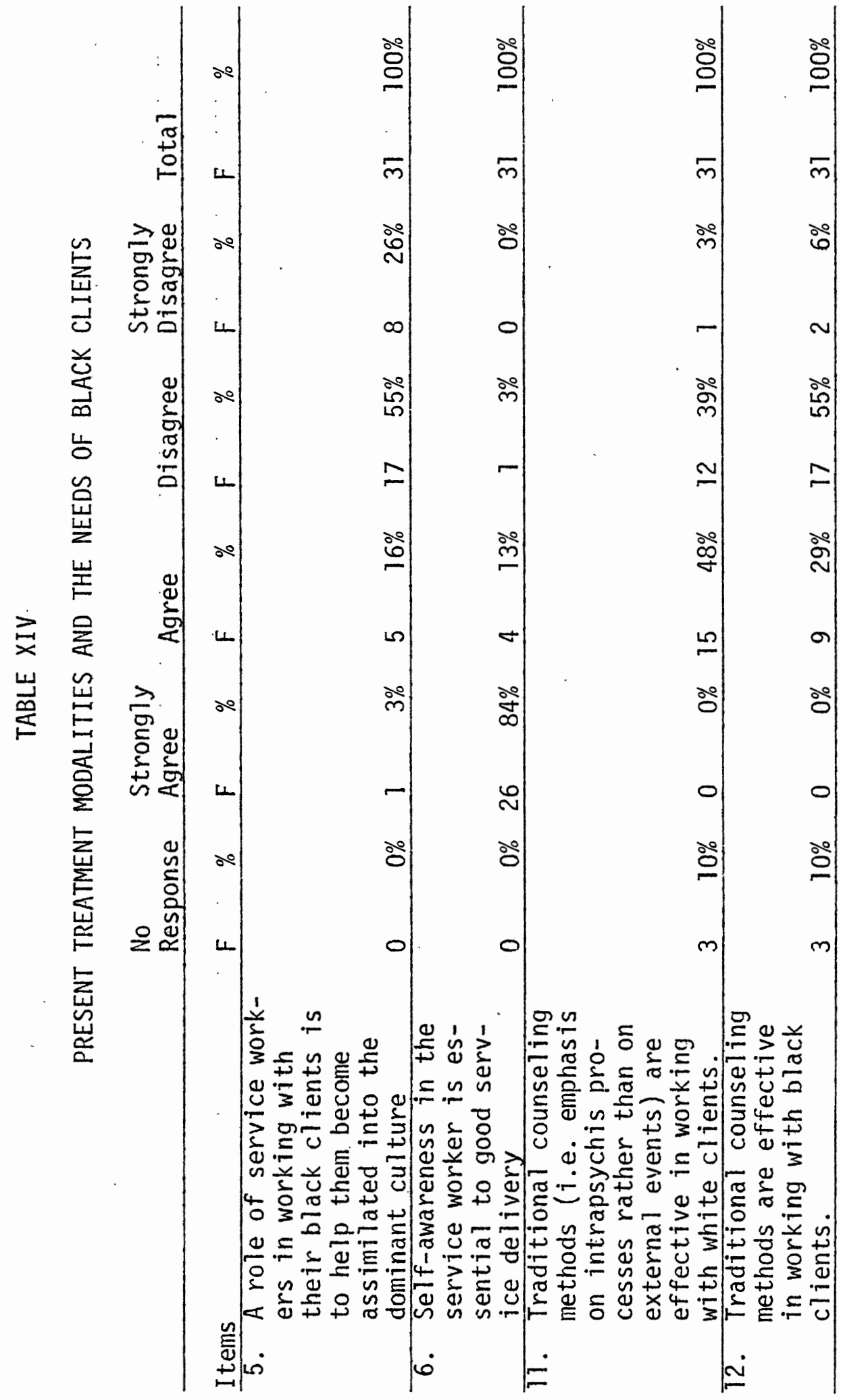




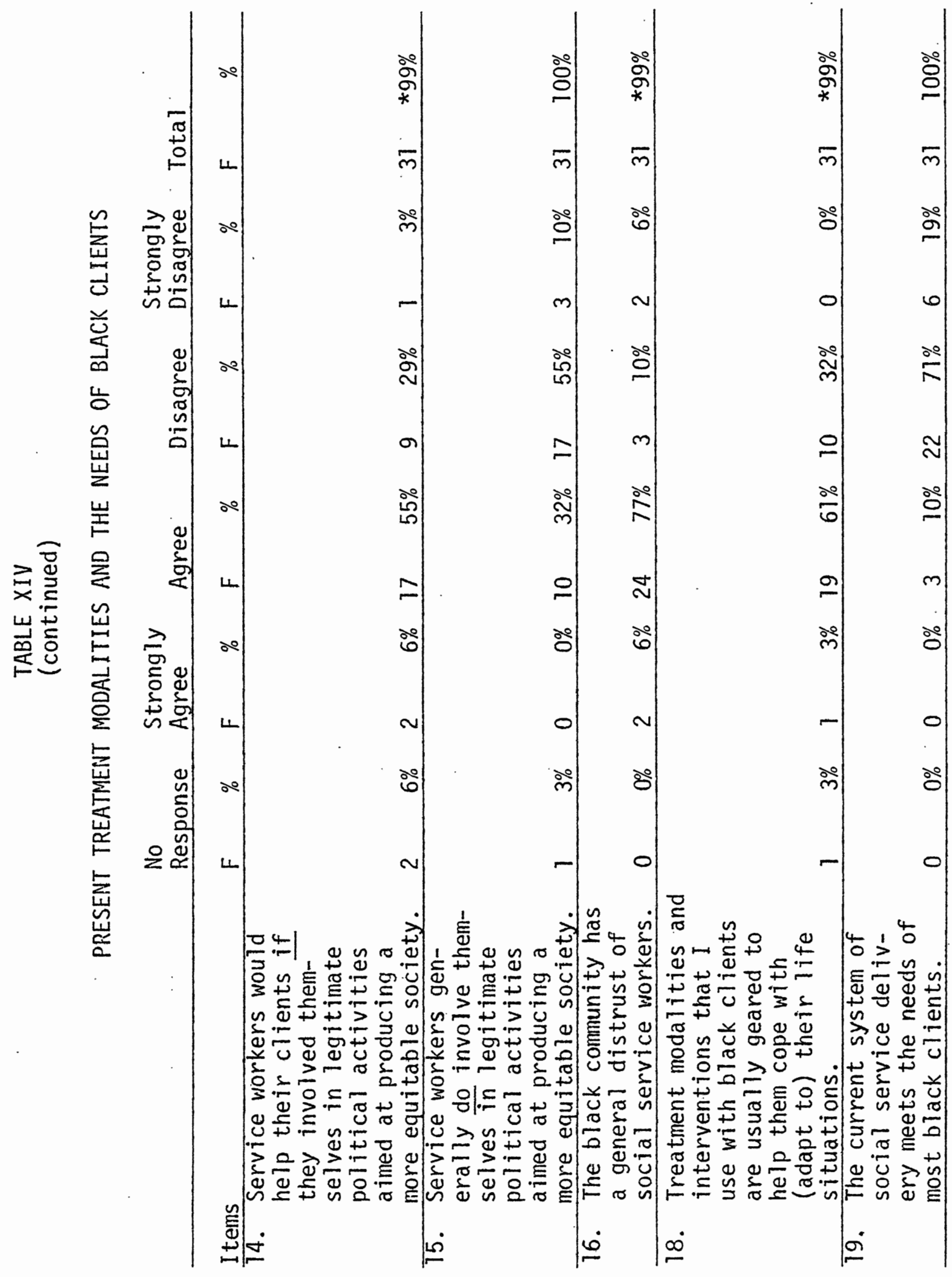




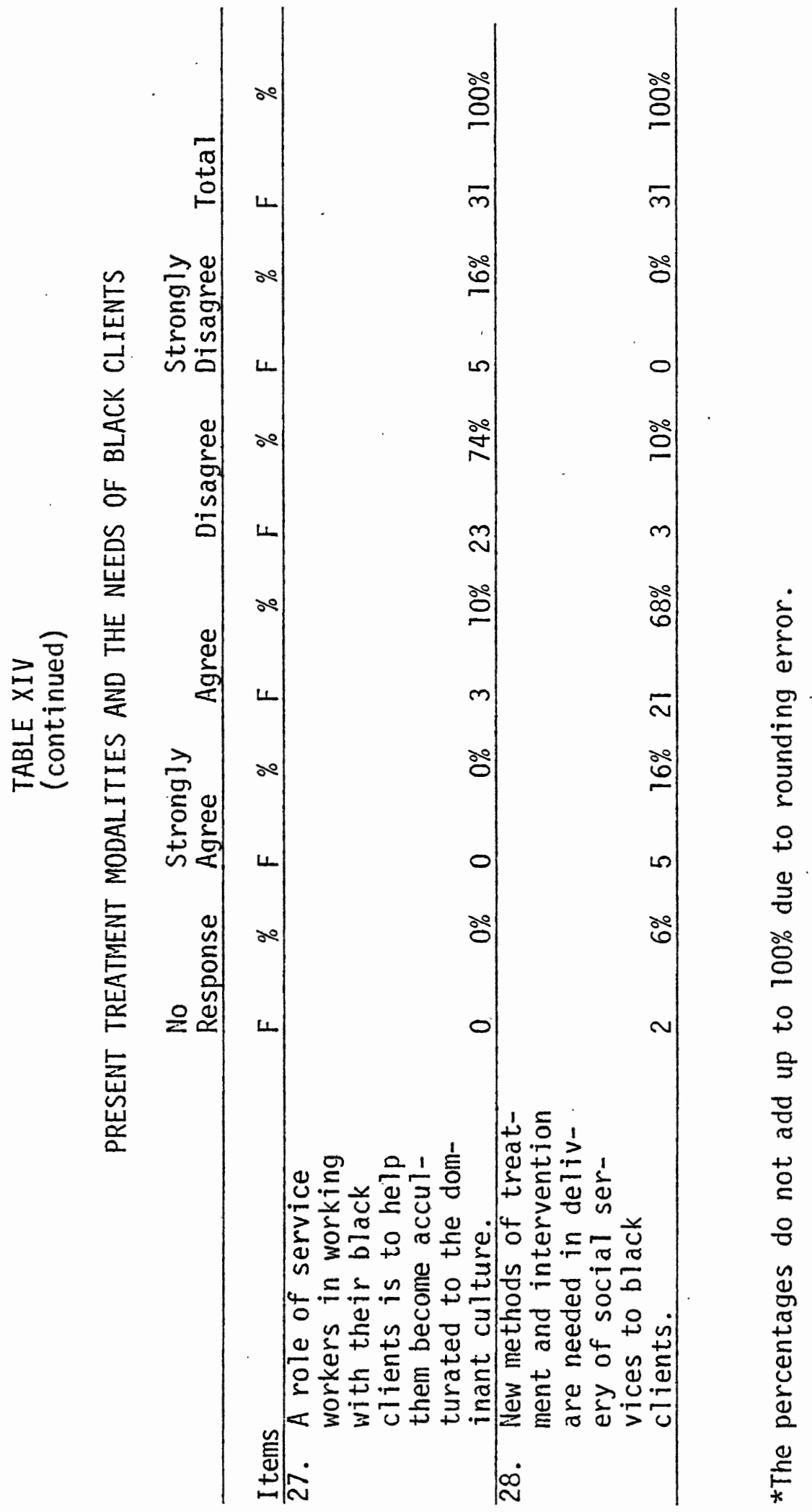


In Table XV, item 2, 97\% of the respondents agree that problems of black families are usually due to socio-economic stresses. Three percent of the workers did not respond to this question. In responding to item 3 , Table XV, $61 \%$ of the service workers feel that problems of both blacks and whites result from the same causes.

The majority of the service workers (65\%) responding to item 4 on Table XV, believe that white workers can never really understand what it is to be black.

In item 8, Table XV, most service workers (94\%) disagree that "a goal of Black Power is to get even with whites for what they have done to black people". Thirty-nine percent strongly disagree with this statement.

Service workers generally agree (74\%) with the statement on Table XV, item 10, "if blacks were given equivalent opportunities in employment and education, they would achieve equality with whites". In item 26, Table XV, the majority of the service workers $(61 \%)$ disagree that if enough we11 run service programs were put into effect, poor black families could get out of their cycle of poverty. Service workers (74\%) generally disagree with this statement: "equalization of status between blacks and whites will not result unless conflict takes place".

Sixty-one percent of the service workers believe that the root causes of depression in both black and white clients are the same. This is noted in Table XV, item 24.

Fifty-one percent of the respondents to item 17, Table XVI, agree that training related to black language patterns would help them to 
better understand the way some blacks express themselves. Ten percent disagree that this kind of training would be helpful to them.

In item 21 , Table XVI, $81 \%$ of the service workers feel that training related to values, norms, and culture of black people would help facilitate their working with black clients. Thirteen percent strongly agree with this statement. 


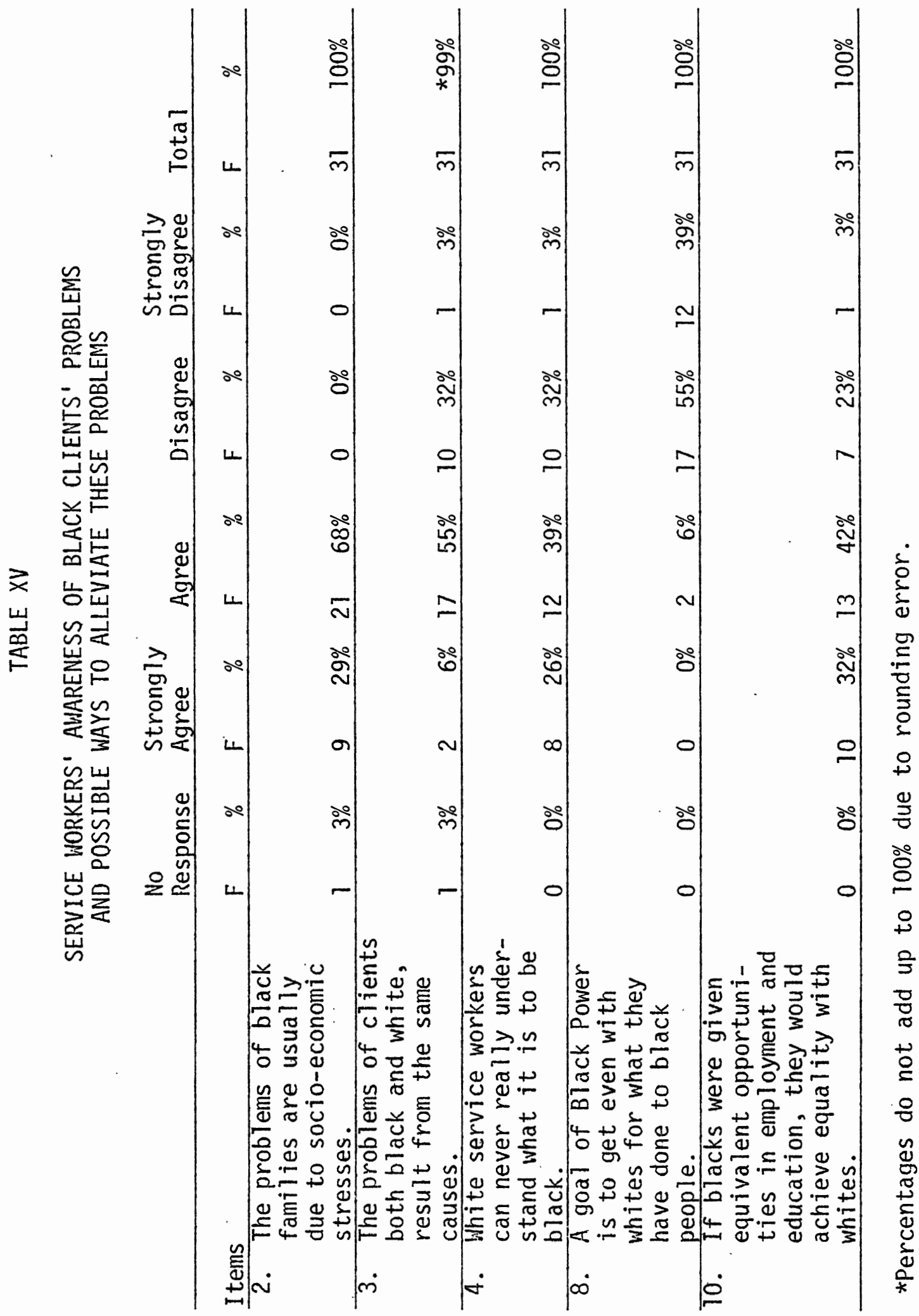




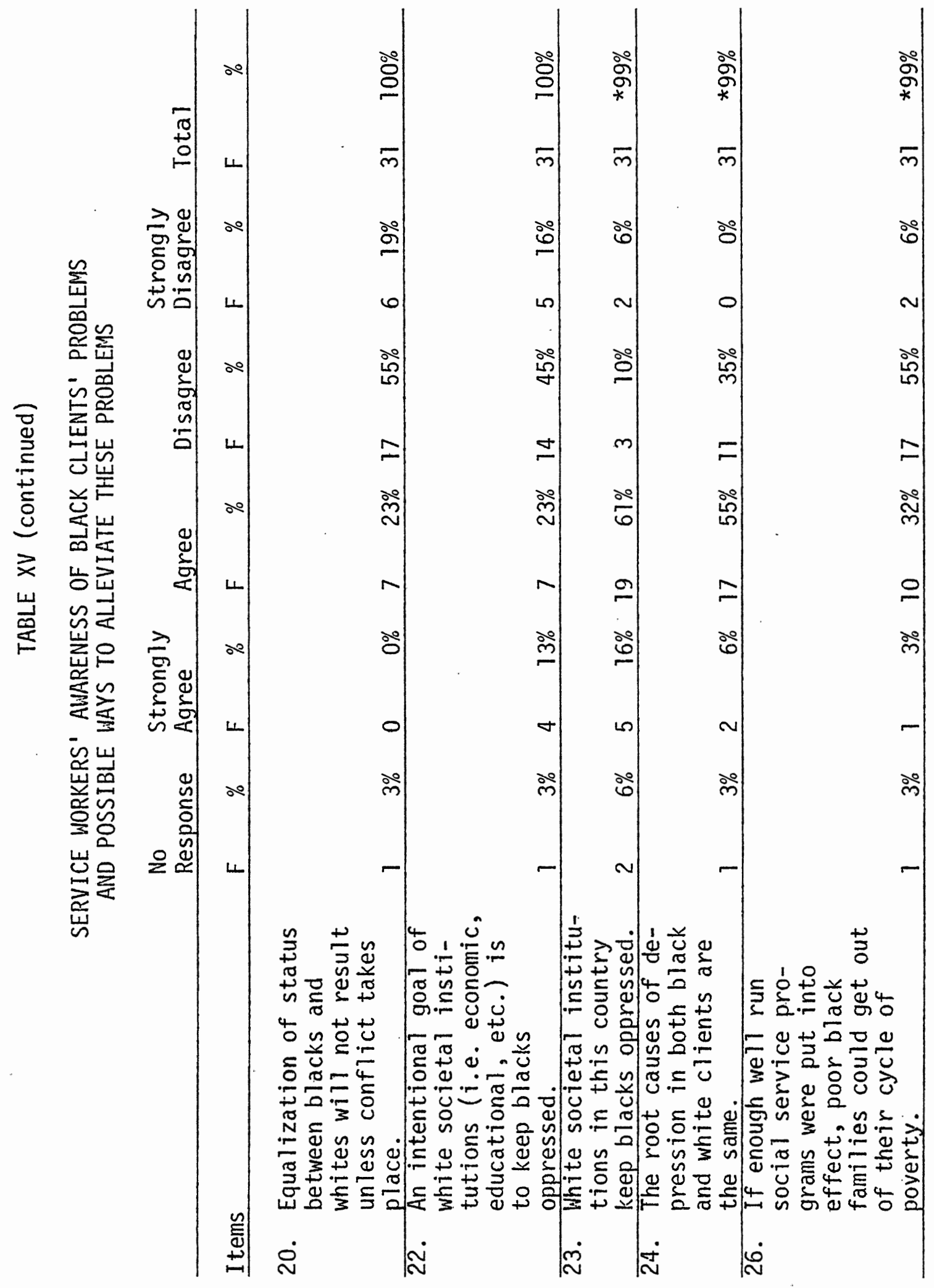




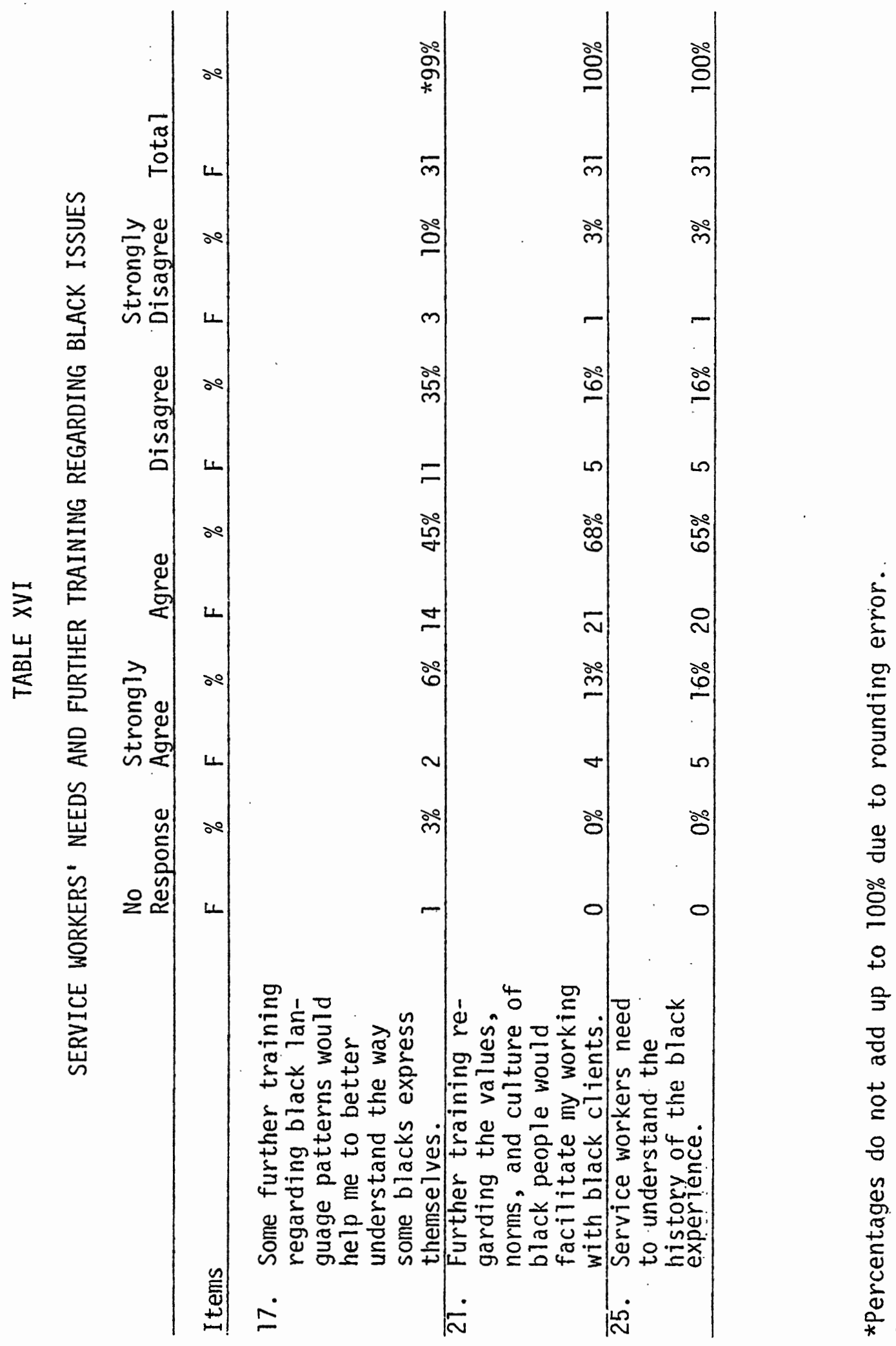


Item 29, which is described in Table xVII, represents an openended question. It asks the respondents to list the areas of training/ education which would be most beneficial to them. Fifteen service workers responded to item 29. A total of 28 responses were elicited from these workers. The numbers on Table XVII reflect, then, multiple responses from the respondents. Nine workers ask for information related to racism, black history, culture, language and so forth, and 6 workers want actual experience with black clients and workers, in order that they might learn to better communicate with blacks. Four workers want information related to black family life and how to effectively intervene when problems arise. Several areas of training mentioned only once: Biblical training, training related to drug counseling, and consultation related to helping black clients find jobs. 
TABLE XVII*

AREAS OF FURTHER TRAINING DESIRED BY SERVICE WORKERS

Number of Responses to Question 29

Information related to racism, black history, culture, language, etc.

Actual experience with black clients and workers to foster communication. 6

Information related to black family life and how to effectively intervene.

Understanding of the economic problems of poor

blacks and particular problems of the Albina area.

Ways to promote trust between black clients and service workers.

2

Biblilical training. 1

Training related to drug counseling. 1

Consultation related to helping black clients

find jobs. 1

Observation of work with black clients by skilled consultants and colleagues. 1

TOTAL 28

*This table represents multiple responses from 15 individual respondents. 
Respondents' Comments

Several of the workers who responded to the survey had feedback for the researchers. The most common feedback concerned the use of terms by the researchers. The term that drew the most comment was "socio-economical7y". Respondents commented that they did not know what was meant by the term. This was also true in the use of "assimilation" and "acculturation" by the researchers. Some workers also questioned what the researchers meant by "strong family unit" and "traditional counseling".

Several respondents said that some of the statements in the questionnaire did not accurately reflect their feelings on specific issues. These workers generally wrote in comments to clarify why they agreed or disagreed with particular statements. A few respondents commented on the survey in general. One such respondent wrote:

I feel that the type of question you are asking tells me

a lot about basic assumptions you have:

(1) that blacks are different from whites; and

(2) because they are different they should be treated differently.

I definitely got a prejudiced feeling when I read this set of questions and felt you were constricting my answers to the limit of your understanding which will not help understand the difficulties of treating people in the black community. 
CHAPTER V.

\section{CONCLUSIONS AND IMPLICATIONS}

\section{The Research Questions}

This study is based on five research questions. Specific questions in the instrument address various aspects of these research questions. The conclusions and implications follow.

\section{Research Question \#1}

Do service workers feel that black life experiences, family life and community life differ from white life experiences, family life and community Tife?

Conclusions and Implications

Responses from workers lead the researchers to conclude that:

1.) Service workers generally feel that black life experiences, family life and community life are different from white life experiences, family life and community life;

2.) The greatest difference is perceived as being between black community life and white community life; and

3.) A7though black family life is seen as different from white family life by a majority of service workers, both the black family, and the family, generally, are felt to be strong units within society.

It is interesting to note that while a majority $(51 \%)$ of service workers see black family life as different from white family life, a 
much higher percentage of respondents (78\%) feel that black community life differs from white community life.

Because questions were not asked regarding how workers define differences between black life experiences and white life experiences, further conclusions are not possible.

\section{Research Question \#2}

Do service workers feel that present service programs and modes of intervention meet the needs of black clients?

Conclusions and Implications

Most workers feel that the current system of service delivery does not meet the needs of black clients and that new methods of intervention are needed.

Some specific issues follow:

1.) Most ( $83 \%)$ of the workers feel that the black community has a general distrust of service workers. The literature supports that this is true in general. The researchers suggest that this distrust may be a fact of life that should not be denied by workers. Instead, workers should attempt to understand and accept the wariness of black clients and work to earn clients' trust.

2.) The majority (65\%) of respondents agree that white workers can never really understand what it is to be black. The literature supports the idea that racism is so intrinsic to the black person's experience, that a person who does not experience racism in its many forms, cannot truly understand what it is to be black. 
3.) Most respondents disagree that a role of service workers is to help black clients become assimilated into ( $81 \%$ disagree) or acculturated to (90\% disagree) the dominant culture, and $64 \%$ of these workers state that interventions they use with black clients are usually geared to help them cope with (adapt to) their life situations.

Respondents to these two questions regarding assimilation and acculturation do not seem to make a distinction between the two terms as evidenced by the similarity of their responses. Also, the researchers would ask if perhaps service workers placed anegative connotation on the term "dominant cuiture". One may oniy speculate as to the reasons why so many workers disagree that their role is to help black clients in assimilation and acculturation.

Even though most workers disagree with the questions regarding assimilation and acculturation, a majority of these workers say that interventions they use with black clients are usually geared to help them cope with (adapt to) their life situations. The researchers consider coping with (adapting to) life situations to be similar to acculturating to the dominant culture, and so, see these responses as being contradictory to each other. It is possible, however, that service workers did not interpret the terms assimilation, acculturation, coping and adapting in the same way as did the researchers.

4.) Service workers seem to be questioning the effectiveness of traditional counseling methods with both black and white clients. Fortyeight percent of the workers feel that traditional methods are effective in working with white clients, while only $29 \%$ feel that traditional methods are effective in working with black clients. 
"Traditional counseling methods." were defined in the questionnaire as methods which place "emphasis on intrapsychic processes rather than on external events". The researchers' understanding of traditional counseling methods is that these methods help clients to cope with their life situations.

In comparing responses to the question regarding adaptation to life situations (see item \#3, above), and the question concerning traditional counseling methods, a contradiction is seen. The researchers note that less than one-third of the workers feel that traditional counseling methods are effective in working with black clients, yet almost two-thirds of the respondents say that interventions they use with black clients help them to cope with their life situations. Again, it is possible that workers did not interpret terms in the same way as did the researchers. Another explanation might be that workers do not see traditional counseling methods as being effective with black clients, but do not know of alterratives to this form of intervention.

5.) Respondents generally agree (67\%) that service workers would help black clients if they (the workers), involved themselves in legitimate political activities aimed at producing a more equitable society. Onty $32 \%$, however, feel that service workers do involve themselves politically for the benefit of black clients.

There are several possible reasons for this political non-involvement on the part of workers. Service workers are not often encouraged by their agencies to participate in political activities by the granting time off or compensatory time; workers might feel that they are expending as much energy as they can in direct service to clients and do not 
have the time or the energy to do more, even though they might see the value in political activity. Also, workers might feel that they are powerless to make political reforms which might benefit black clients.

6.) Almost all (97\%) of the respondents agree that self-awareness in the service worker is essential to good service delivery. The literature points out that the process of becoming self-aware, when working with black clients, includes a process of dealing with one's own feelings about race and racism.

Research Question \#3

What are some of the root causes of problems that black clients have? What means might be employed to help alleviate these problems?

\section{Conclusions and Implications}

Items number one and two, below, are concerned with possible causes of problems of black clients. Item three asks service workers to evaluate a few possible solutions to these problems, and item four attempts to ascertain service workers' feelings regarding the Black Power movement and the role of conflict in the equalization of status between blacks and whites.

A limitation of the instrument in addressing this particular research question is that the researchers did not specifically ask to what extent racism, individual and institutional, contributes to the problems of blacks.

1.) Most $(77 \%)$ of the service workers agree that white societal institutions keep blacks oppressed but a majority (61\%) disagree that this oppression is intentiona?. 
The literature points out that institutional racism exists in the United States in many forms. Some acts of institutional racism are blatant such as segregation in schools. Others are more subtle acts such as the use of intelligence tests which assume white-middle class experiences and values. There is no agreement as to whether institutional racism is an intentional act or not. The researchers suggest, however, that service workers recognize the effects of institutional racism as being forms of oppression in their black clients' lives.

2.) A17 of the respondents agree that problems of black families are usually due to socio-economic stresses. Sixty-one percent of the service workers feel that problems of both black and white clients result from the same causes and $67 \%$ believe that the root causes of depression in both black and white clients are the same.

Service workers seem to recognize that problems of black families ultimately result from socio-economic stresses. The researchers find it interesting that $61 \%$ of the respondents feel that problems of black and white clients result from the same causes and that $61 \%$ of the service workers see root causes of depression as being the same in both black and white clients.

Two logical deductions seem to follow from these results. First, if socio-economic stress is generally seen as the cause of problems of black families and if $61 \%$ of the respondents feel that causes of black and white clients' problems are the same, then it would follow that $61 \%$ of the workers see the cause of white families' problems as being due to socio-economic stresses. Second, if socio-economic stress is generally see as the cause of problems of black families and if $61 \%$ of 
the respondents feel that the root causes of depression in black and white clients are the same, then it appears that the service workers generally feel that depression in black clients is caused by socioeconomic stresses and that $61 \%$ of these workers feel that the cause of depression in white clients is also due to socio-economic stresses.

Traditional counseling methods, which are discussed in research question \#2, item 4, above, are seen as being effective with black clients by less than one-third of the respondents. Perhaps these methods are seen as largely ineffective because they focus upon internal (intrapsychic) processes rather than upon external events. The responses regarding the causes of black families' problems indicate that these problems are usually due to external stresses. It is reasonable to assume then, that methods of intervention which focus on externally caused stresses might be more effective in working with black clients than those which focus on intrapsychic processes.

In asking these questions related to the causes of problems of both black and white clients, the researchers employed terms which were somewhat different in meaning from each other, for example, "black families": "black clients"; "root causes": "usually due to...". Because these different terms were used, statements regarding comparisons between black and white clients, as to the causes of their problems are not possible.

Item number three asks service workers to evaluate a few possible solutions to problems which blacks have.

3.) Service workers generally agree (74\%) that if blacks were given equivalent opportunities in employment and education, they would 
achieve equality with whites. The majority $(61 \%)$ disagree, however, that if enough well run service programs were put into effect, that poor black families could get out of their cycle of poverty.

Respondents seem to agree that equality will not result from initiating service programs to aid poor black farnilies but will be possible only if blacks are given equivalent opportunities in employment and education. The literature bears out these findings.

Item number four attempts to ascertain service worker's feelings regarding the Black Power movement and the role of conflict in the equalization of status between blacks and whites.

4.) Most service workers. (94\%) disagree that a goal of black power is to get even with whites for what they have done to black people and $74 \%$ disagree with the statement "equalization of status between blacks and whites will not result unless conflict takes place".

The role of conflict in societal change is discussed briefly in the literature review. The researchers are aware that there are severa. points of view which address the necessity of conflict regarding equalization of status between blacks and whites. These diverse points of view take several factors into consideration. Among these factors are: the necessity of any form of conflict, the immediacy of the conflict, the intensity of the conflict and the violence of the conflict. The researchers assume that it has been demonstrated historically, that people with power do not usually give up that power willingly. It is not being suggested that conflict necessarily means violent confrontation between blacks and whites. It is possible, however, that service workers defined the term "conflict" in this way. This could account for 
the high percentage of respondents who disagree with the statment regarding the necessity of conflict to equalization of status between blacks and whites.

The researchers also question the validity of the response to the question regarding Black Power. Because an evocative phrase, "get even with whites" was used, it cannot be ascertained whether or not workers' responses reflected their reactions to that phrase.

\section{Research Question \#4}

Do service workers feel that training regarding black history, culture, values, norms and language patterns would help facilitate their working with black clients?

\section{Conclusions and Implications}

Most (81\%) workers agree that training regarding black history, culture, values and norms would be beneficial to them in their work with black clients. A smaller percentage of respondents (51\%) also feel that an understanding of black language patterns would be helpful.

It is probable that fewer workers want training regarding language patterns because black respondents probably would not find this training necessary in most cases.

\section{Research Question \#5}

Which areas of training related to most effective service delivery to black clients would service workers find most beneficial?

Conclusions and Implications

Table XV shows the specific results of this question. In general, 
the researchers conclude that workers would benefit from both didactic and experiential learning regarding racism, black history, culture, values, and so forth. Several workers state that honest communication between blacks and whites would contribute to better understanding between the two groups.

\section{$\underline{\text { Summary }}$}

Respondents to this survey generally show an understanding of black clients and of their world. They seem to question the effectiveness of traditional treatment modes in working with black clients, however. They feel that new methods of intervention are needed. Workers state that they would like further training regarding black issues. They would find a combination of didactic and experiential learning in many aspects of the black experience to be most beneficial. 


\section{CHAPTER VI}

\section{SUMMARY AND RECOMMENDATIONS}

This study was undertaken as a result of the researchers' interest in racism. It reflects their concern over the lack of emphasis in acknowledging the factor of race in working with black clients.

The literature documents the influence of racism on the lives of black people. Racism is apparent in all aspects of life. It may take the form of individual, institutional or cuitural racism.

Racism in Portland was first manifested through law in the exclusion statutes which virtually kept blacks out of the state of Oregon until the late 1920's. Today, racism in Portland is evidenced in more subtle forms: in the high unemployment rate of black youth; in the low numbers of black police people and community leaders; in the lack of emphasis in the School of Social Work to prepare social workers for work with black clients.

In reviewing the literature regarding interventions with black clients, it is emphasized that effective interventions will not take place with these clients unless the issue of race is discussed. Several authors maintain that both clients and workers have strong feelings regarding race and that these feelings must be dealt with before effective client treatment can take place.

Workers are urged to maintain the delicate balance between the client's blackness and his/her personness. They are advised to maintain a professional vision in treatment which emphasizes hope and 
growth for both the client and worker.

Education for work with minority clients is a means to combat racism within the social work profession. This education may take place both in schools of social work and within community based agencies. While authors differ as to how much effect education has on racist attitudes, it is generally agreed upon that education is able to make an impact at particular levels.

The researchers surveyed service workers who provide counseling and/or therapy to black clients. Questions were asked regarding workers' perceptions of black life experiences, the causes of black clients' problems, and possible ways to alleviate these problems. Workers were asked if they feel that present modes of intervention are effective in working with black clients. The researchers also inquired if workers would benefit from further training regarding black issues and asked these workers to list which areas of training would be most helpful to them.

\section{Summary of Data}

Respondents generally seem to show an understanding of the black client's world. They acknowledge it as different from the dominant culture and do not, for the most part, judge black values and life experiences according to white standards. Workers also seem to recognize institutional recism and the impact of socio-economic factors on black families.

Service workers do not feel that the present system of service delivery effectively meets the needs of black clients. These workers would like further training in the form of didactic and experiential 
learning in many aspects of the black experience.

Recommendations

The researchers recommend that education for work with black clients be given a renewed emphasis. This needs to be implemented on two levels. First, the School of Social Work should revise its curriculum to include more courses on blacks and the program of field experience for students wishing to work in the black community should be expanded and given more support. A7so, a greater emphasis should be placed on minority recruitment of students and staff. Second, an intensive series of inservice programs should be instituted within community based agencies. These inservice programs, to be more beneficial, would emphasize the workers' understanding of black clients' life experiences. They would have as a primary goal an increase in workers' self-awareness and sensitivity to the issue of racism and how it impinges on the lives of black clients. Agencies within the Albina community in particular, should be concerned about preparing workers to serve black clients, as the greatest proportion of Portland's blacks live in this area of the city.

The respondents to the survey conducted by the researchers requested training that would be both didactic and experiential. The literature affirms the fact that learning, if it is to be integrated, must occur on both cognitive and affective levels.

The researchers recommend that agency-specific needs assessments regarding training needs of workers be done. The results of these assessments should be utilized in planning a series of inservice training 
programs. Perhaps graduate students in the School of Social Work could undertake this project within individual agencies to fulfill their research requirements for graduation. Agency time should be allotted, and ideally, two facilitators, one black and one white, who do not serve in a supervisory capacity over workers, should be brought in to lead the inservice sessions. A sufficient number of sessions must be allotted to the discussion of racism and to the sharing of experiences between black and white workers. It should be anticipated that this discussion of racial issues, if it is to go beyond a superficial level, will elicit painful feelings of anger, guilt and depression. It may also induce a sense of hopelessness in workers who participate. These possible outcomes need to be anticipated and dealt with.

Although this series of inservice sessions may represent a painful process of self-discovery for workers, it should result in a keener sense of self-awareness and a sharpened sense of the meaning of racism in black clients' lives. Ultimately, this experience of self-discovery and acquisition of new knowledge regarding the experience of racism should prepare workers to better understand and more effectively serve their black clients. 


\section{LIST OF FOOTNOTED REFERENCES}

1. Random House Dictionary of the English Language, 1967 ed. s.v. "discrimination."

2. Ibid., s.v. "prejudice."

3. Stokely Carmichael and Charles V. Hamilton, Black Power: The Politics of Liberation in America (New York: Alfred A. Knopf and Random House, 1967, p. 3.

4. Random House Dictionary, s.v. "acculturation."

5. Joel Kovel, White Racism: A Psychohistory (New York: Pantheon Books, 1970), P. XIX.

6. Andrew Billingsley, Black Families in White America (Englewood Cliffs, N.J.: Prentice-HaT1, Inc., 1968), p. 152.

7. Random House Dictionary, s.v. "institution."

8. Lewis L. Knowles and Prewitt, Kenneth, eds. Institutional Racism in America (Englewood Cliffs, N.J.: Prentice-Ha17, Inc., 1969), p. 5 .

9. Ibid., p.6.

10. Carmichael and Hamilton, p. 4.

11. William Ryan, Blaming the Victim (New York: Random House, 1971), pp. 80-81.

12. Ibid., p. 82 .

13. Ibid., p. 83 .

14. Carmichael and Hamilton, p. 44.

15. Kove1, p. 8.

16. Lenwood G. Davis, "Blacks in the Pacific Northwest 1788-1972: A Bibliography of Published Works and of Unpublished Source Materials on the Life and Contributions of Black People in the Pacific Northwest" (Portland State University, Portland, Oregon, 1972), p. 3.

17. Diane Pancoast, "How Portland Got a Ghetto: the White Response to Black Migration in the Forties", Portland, Oregon, 10 June 1975, p. 22. 
18. "Young Blacks Tired of 'Don't Cal1 Us, We'11 Call You'," Alan K. Ota, Oregonian, 29 January 1978, sec. D., p. 1.

19. It should be noted that most of the youth represented on the "Town Hall" broadcast were students at a high school where blacks comprise the majority of the student body. The fact that these young people are not in the minority in their school situation may serve to lessen the perceived effects of racism in their lives.

20. Encyclopedia of Social Work, 1965 ed., s.v. "social casework," by Helen Harris Perlman, p. 706.

21. Alex Gitterman and Alice Schaeffer, "The White Professional and the Black Client", in Dynamics of Racism in Social Work Practice, ed. James A. Goodman (Washington, D.C.: N.A.S.W., 1973), P. 153;

01 ive Petro and Betty French, "The Black Client's View of Himself", ibid., p. 114; Howard D. Kibel, "Interracial Conflicts as Resistance in Group Psychotherapy", ibid., p. 222; Clemmont E. Vontress, "Racial Differences: Impediments to Rapport", ibid., pp. 82-83; Petro and French, p. 124; Shirley Cooper, "A Look at the Effect of Racism on Clinical Work", ibid., p. 129; James H. Carter and Thomas M. Haizlip, "Race and Its Relevance to Transference", ibid., pp. 171-178.

22. Carmichael and Hamilton, p. 4.

23. David R. Burgest, "Racism in Everyday Speech and Social Work Jargon," Social Work, vol. 18, no. 4, July 1973, p. 25.

24. Marta Sotomayor, "Language, Culture, and Ethnicity in Developing Self-Concept," Social Casework, April 1977, p. 196.

25. Barbara Bryant Solomon, "Traditional Treatment Approaches and the Minority Client," (Paper presented to the Western Regional Horkshop of the Family Service Association of America, Asilomar Conference Center, Pacific Grove, California, 13 June 1976), p. 3.

26. Sotomayer, p. 202.

27. David Claerbaut, Black Jargon in White America (Grand Rapids, Michigan: William D. Eerdmans Pub7ishing Company, 1972), p. 47.

28. Random House Dictionary, S.v. "culture."

29. Kibel, p. 222; Petro and French, p. 124; Stiles, et al., p. 189.

30. Burgest, p. 23.

31. William H. Grier and Price M. Cobbs, Black Rage, with a Foreword by United States Senator Fred R. Harris (New York: Bantam Books, 1968), p. 2 . 
32. Clifford J. Sager, Thomas L. Brayboy and Barbara R. Waxenberg, "Black Patient -- White Therapist", in Dynamics of Racism, p. 145.

33. Claerbaut, p. 12.

34. Cooper, p. 128.

35. Petro and French, p. 114.

36. Carmichael and Hamilton, p. 6.

37. Bertha L. Doremus, "The Four R's: Social Diagnosis in Health Care", Health and Social Work, vol. 1, no. 4, November 1976.

38. Although Doremus developed her model for use in health care settings, the researchers believe that it can be used effectively in other settings as well.

39. Billingsley, p. 10 .

40. Cooper, p. 133.

41. Perlman, pp. 706-707.

42. John Longres, "The Impact of Racism on Social Work Education", in Dynamics of Racism, P. 303; John B. Turner, "Education for Practice with Minorities, ibid., P. 310; Lawrence E. Gary, "Social Work Education and the Black Community: A Proposal for Curriculum Revisions", ibid., p. 321; Mary Ella Robertson, "Inclusion of Content on Ethnic and Racial Minorities in the Social Work Curriculum", ibid., pp. 330-337.

43. John M. Howley, Jr., "An Agency's Preparation for Internal Advocacy", Social Casework, vol. 53, no. 4, 1972; Pauline D. Lide "Dialogue on Racism: A Prologue to Action?", in Dynamics of Racism, pp. 12-21; Petro and French, p. 114.

44. Marie Simmons Saunders, "The Ghetto: Some Perceptions of a Black Social Worker", in Dynamics of Racism, p. 269.

45. How Tey, p. 206.

46. Ibid., p. 207.

47. Ibid., p. 208.

48. Billy J. Tidwell, "The Black Community's Challenge to Social Work", in Dynamics of Racism, p. 252.

49. Barbara E. Shannon, "Implications of White Racism for Social Work Practice", Social Casework, vol. 51, May 1970, p. 272.

50. Petro and French, p. 125. 


\section{SELECTED BIBLIOGRAPHY}

Books

Baldwin, James. The Fire Next Time. New York: Dell Publishing Co., Inc., 1962 .

Billingsley, Andrew. Black Families in White America. Inglewood, N.J.: Prentice-Ha11, Inc., 1968.

Carmichael, Stokely and Hamilton, Charles V. Black Power: The Politics of Liberation in America. New York: Vintage Books, A Division of Random House, 1967.

Claerbaut, David. Black Jargon in White America. Grand Rapids, Michigan: WilTiam D. Eerdmans Publishing Company, 1972.

Dahrendorf, Ralf. Class and Class Conflict in Industrial Society. Stanford: Stanford University Press, 1959.

Dubois, W. E. Burghardt. The Souls of Black Folk. Introduction by Saunders Redding. Greenwich, Conn.: Fawcett Publications, Inc., 1953.

Goodman, James A., ed. Dynamics of Racism in Social Work Practice. Washington, D.C.: National Association of Social Workers, Inc., 1973.

Grier, William H. and Cobbs, Price M. Black Rage. Foreword by U.S. Senator Fred R. Harris. New York: Basic Books, Inc., 1968.

Killian, Lewis and Grigg, Charles. Racial Crisis in America: Leadership in Conflict. Englewood Cliffs, N.J.: Prentice-Hall, Inc., 1964 .

King, Martin Luther, Jr. Why We Can't Wait. New York: The New American Library, Inc., 1963.

Knowles, Louis L. and Prewitt, Kenneth, eds. Institutional Racism in America. Englewood Cliffs, N.J.: Prentice-Hal1, Inc., 1969.

Kove1, Joe1. White Racism: A Psychohistory. New York: Pantheon Books, 1970.

Liebow, Elliot. Tally's Corner. Boston: Little, Brown and Company, 1966. 
Books

Random House Dictionary of the English Language: The Unabridged Edition. New York: Random House, 1967.

Ryan, William. Blaming the Victim. New York: Random House, 1971. 
Articles

Brayboy, Thomas L. and Marks, Malcom J. "Transference Variations Evoked by Racial Differences in Co-Therapists." In Dynamics of Racism in Social Work Practice, pp. 214-20. Edited by James A. Goodman. Washington, D.C.: N.A.S.W., Inc., 1973.

Carter, James H. and Haizlip, Thomas M. "Race and Its Relevance to Transference." In Dynamics of Racism in Social Work Practice, pp. 171-8. Edited by James A. Goodman. Washington, D.C.: N.A.S.W., Inc., 1973.

Cohen, Jerome. "Race as a Factor in Social Work Practice." In Dynamics of Racism in Social Work Practice, pp. 90-110. Edited by James A. Goodman. Washington, D.C.: N.A.S.W., Inc., 1973.

Cooper, Shirley. "A Look at the Effect of Racism on Clinical Work." In Dynamics of Racism in Social Work Practice, pp. 127-40. Edited by James A. Goodman. Washington, D.C.: N.A.S.H., Inc., 1973.

Fischer, Newe11. "An Interracial Analysis: Transference and Countertransference Significance." In Dynamics of Racism in Social Work Practice, pp. 205-13. Edited by James A. Goodman. Washington, D.C.: N.A.S.W., Inc., 1973.

Gary, Lawrence E. "Social Work Education and the Black Community: A Proposal for Curriculum Revisions." In Dynamics of Racism in Social Work Practice, pp. 316-29. Edited by James A. Goodman. Washington,D.C.: N.A.S.W., Inc., 1973.

Glasgow, Douglas. "Black Power Through Community Control." In Dynamics of Racism in Social Work Practice, pp. 256-63. Edited by James A. Goodman. Washington, D.C.: N.A.S.H., Inc., 1973.

Gitterman, Alex and Schaeffer, Alice. "The White Professional and the Black Client." In Dynamics of Racism in Social Work Practice, pp: 152-70. Edited by James A. Goodman. Washington, D.C.: N.A.S.W., Inc., 1973.

Graff, Harold, Kenig, Lana and Radoff, Geoffery. "Prejudice of UpperClass Therapists against Lower-Class Patients." In Dynamics of Racism in Social Work Practice, pp. 191-204. Edited by James A. Goodman. Washington, D.C.: N.A.S.W., Inc., 1973.

Howley, John M., Jr. "An Agency's Preparation for Internal Advocacy." Social Casework, vol. 53, no. 4 (1972): 204-8. 
Articles

Kibel, Howard D. "Interracial Conflicts as Resistance in Group Psychotherapy." In Dynamics of Racism in Social Work Practice, pp. 221-9. Edited by James A. Goodman. Washington, D.C.: N.A.S.W., Inc., 1973.

Kolodny, Raiph L. "Ethnic Cleavages in the United States: An Historical Reminder to Social Workers." In Dynamics of Racism in Social Work Practice, pp. 39-55. Edited by James A. Goodman. Washington, D.C.: N.A.S.W., Inc., 1973.

Kurzman, Paut A. "The Native-Settler Concept: Implications for Community Organization." In Dynamics of Racism in Social Work Practice, pp. 56-65. Edited by James A. Goodman. Washington, D.C.: N.A.S.W., Inc., 1973.

Lewis, Hylan. "Race, the Polity, and the Professionals." In Dynamics of Racism in Social Work Practice, pp. 22-38. Edited by James A. Goodman. Washington, D.C.: N.A.S.W., Inc., 1973.

Lide, Pauline D. "Dialogue on Racism: A Prologue to Action?" In Dynamics of Racism in Social Work Practice, pp. 12-21. Edited by James A. Goodman. Washington, D.C.: N.A.S.W., Inc., 1973.

Longres, John. "The Impact of Racism on Social Work Education." In Dynamics of Racism in Social Work Practice, pp. 297-305. Edited by James A. Goodman. Washington, D.C.: N.A.S.W., Inc., 1973.

Miller, Henry. "Social Work in the Black Ghetto: The New Colonialism." In Dynamics of Racism in Social Work Practice, pp. 271-87. Edited by James A. Goodman. Washington, D.C.: N.A.S.W., Inc., 1973.

Perlman, Helen Harris. "Social Casework." Article in Encyclopedia of Social Hork. Harry L. Lurie, ed., (New York: N.A.S.W., T965), pp. 704-15.

Petro, 01 ive and French, Betty. "The Black Client's View of Himself." In Dynamics of Racism in Social Work Practice, pp. 113-26.

Edited by James A. Goodman. Washington, D.C.: N.A.S.W., Inc., 1973.

Robertson, Mary Ella. "Inclusion of Content on Ethnic and Racial Minorities in the Social Work Curriculum." In Dynamics of Racism in Social Work Practice, pp. 330-7. Edited by James A. Goodman. Washington, D.C.: N.A.S.W., Inc., 1973.

Sager, Clifford J., Brayboy, Thomas L. and Waxenberg, Barbara R. "Black Patient - White Therapist." In Dynamics of Racism in Social Work Practice, pp. 141-51. Edited by James A. Goodman. Washington, D.C.: N.A.S.W., Inc., 1973. 
Articles

Saunders, Marie Simmons. "The Ghetto: Some Perceptions of a Black Social Worker." In Dynamics of Racism in Social Work Practice, pp. 26470. Edited by James A. Goodman. Washington, D.C.: N.A.S.W., Inc., 1973.

Shannon, Barbara E. "Implications of White Racism for Social Work Practice." Social Casework. vo1. 51, no. 5 (May 1970): 270-6.

Siegel, J.M. "A Brief Review of the Effects of Race on Clinical Service Interactions." American Journal of Orthopsychiatry. vol. 44 , no. 4 (1974): 555-62.

Solomon, Barbara Bryant. "Traditional Treatment Approaches and the Minority CTient." Paper presented to the Western Regional Workshop of the Family Service Association of America, Asilomar Conference Center; Pacific Grove, California. 13 June 1976.

Sotomayor, Marta. "Language, Culture and Ethnicity in Developing SelfConcept." Social Casework (April 1977): 195-203.

Stiles, Evelyn, Donner, Susan, Giovannone, Jean, Lochte, Elizabeth and Reetz, Rebecca. "Hear It Like It Is." In Dynamics of Racism in Social Work Practice, pp. 179-90. Edited by James A. Goodman. Washington, D.C.: N.A.S.W., Inc., 1973.

Tidwe11, Billy J. "The Black Community's Challenge to Social Work." In Dynamics of Racism in Social Work Practice, pp. 247-55. Edited by James A. Goodman. Washington, D.C.: N.A.S.W., Inc., 1973.

Turner, John B. "Education for Practice with Minorities." In Dynamics of Racism in Social Work Practice, pp. 306-15. Edited by James A. Goodman. Washington, D.C.: N.A.S.W., Inc., 1973.

Vontress, Clemmont E. "Racial Differences: Impediments to Rapport." In Dynamics of Racism in Social Work Practice, pp. 80-9. Edited by James A. Goodman. Washington, D.C.: N.A.S.W., Inc., 1973. 


\section{Other Sources}

Baker, Dorothy L., Richberg, Alexander, and White, Isaac. "Black Content in Schools: A Model of Black Content in a School of Social Work's Curriculum." M.S.W. research practicum, Portland State University, Portland, Oregon, December 1973.

Davis, Lenwood G. "Blacks in the Pacific Northwest 1788-1972: A Bibliography of Published Works and of Unpublished Source Materials on the Life and Contributions of Black People to the Pacific Northwest." Portland State University, Portland, Oregon, 1972.

Herndon, Ron. Interview regarding racism in Portland. Portland, Oregon. 31 May 1977.

KATU. "Town Ha11." 2 October 1977, Discussion of Racism in Portland.

Pancoast; Diane. "How Portland Got a Ghetto: The White Response to Black Migration in the Forties." Portland, Oregon. 10 June 1975.

"Young Blacks Tired of Don't Call Us, We'11 Call You." Ota, Alan K. Oregonian, 29 January 1973, sec. D., p. 1. 
APPENDIX I

QUESTIONNAIRE

Background Information

1. Sex: Male __ Female

2. Age

3. Racial background:

Black

Chicano White

Asian American Native American Other

4. Academic history:

High School: Yes No

Number of years of education beyond high school

Degree $(\$)$ received

Field or major

5. Size of community in which you spent most of your childhood:

15,000 and under

15,000 to 50,000

50,000 to 100,000

100,000 to 500,000

500,000 and over

6. Geographical area where you were raised:

West

East

South

North 
7. Income level at the present time:

$$
\begin{aligned}
& 0-4,999 \\
& 5,000-9,999 \\
& 10,000-14,999 \\
& 15,000-19,999 \\
& 20,000 \text { and up }
\end{aligned}
$$

8. Approximate number of individuals to whom you are providing direct services

9. Regarding the individuals to whom you are providing direct services, what percentage is:

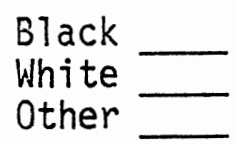

10. Approximately how many years have you been providing services to:

$$
\begin{aligned}
& \text { Black clients years } \\
& \text { White clients years } \\
& \text { Others years ye yers }
\end{aligned}
$$

11. The majority of direct services you provide are to:

Families

$$
\begin{aligned}
& \text { IndividuaTs } \\
& \text { Groups } \\
& \text { Other (specify) }
\end{aligned}
$$

12. The services you provide are mainly:

Voluntary (clients choose to come in for services) Involuntary (mandated)

13. Degree of satisfaction with job:

High

Medium

Low 
14. Do you reside in Albina:

Yes

No 
Circle the number that best expresses your feelings.

1. The black family is an example of a strong unit within society.

$\begin{array}{cccc}1 & 2 & 3 & 4 \\ \begin{array}{l}\text { strongly } \\ \text { agree }\end{array} & \text { agree } & \text { disagree } & \begin{array}{l}\text { strongly } \\ \text { disagree }\end{array}\end{array}$

2. The problems of black families are usually due to socioeconomic stresses.

$\begin{array}{cccc}1 & 2 & 3 & 4 \\ \begin{array}{l}\text { strongly } \\ \text { agree }\end{array} & \text { agree } & \text { disagree } & \begin{array}{l}\text { strongly } \\ \text { disagree }\end{array}\end{array}$

3. The problems of clients both black and white, result from the same causes.

$\begin{array}{cccc}1 & 2 & 3 & 4 \\ \begin{array}{l}\text { strongly } \\ \text { agree }\end{array} & \text { agree } & \text { disagree } & \begin{array}{l}\text { strongly } \\ \text { disagree }\end{array}\end{array}$

4. White service workers can never really understand what it is to be black.

$\begin{array}{cccc}1 & 2 & 3 & 4 \\ \begin{array}{l}\text { strongly } \\ \text { agree }\end{array} & \text { agree } & \text { disagree } & \begin{array}{l}\text { strongly } \\ \text { disagree }\end{array}\end{array}$

5. A role of service workers in working with their black clients is to help them become assimilated into the dominant culture.

$\begin{array}{cccc}1 & 2 & 3 & 4 \\ \begin{array}{l}\text { strongly } \\ \text { agree }\end{array} & \text { agree } & \text { disagree } & \begin{array}{l}\text { strongly } \\ \text { disagree }\end{array}\end{array}$


6. Self-awareness in the service worker is essential to good service delivery.

$\begin{array}{cccc}1 & 2 & 3 & 4 \\ \begin{array}{l}\text { strongly } \\ \text { agree }\end{array} & \text { agree } & \text { disagree } & \begin{array}{l}\text { strongly } \\ \text { disagree }\end{array}\end{array}$

7. Black family life is different from white family life.

$\begin{array}{cccc}1 & 2 & 3 & 4 \\ \begin{array}{l}\text { strongly } \\ \text { agree }\end{array} & \text { agree } & \text { disagree } & \begin{array}{l}\text { strongly } \\ \text { disagree }\end{array}\end{array}$

8. A goal of Black Power is to get even with whites for what they have done to black people.

$\begin{array}{cccc}1 & 2 & 3 & 4 \\ \begin{array}{l}\text { strongly } \\ \text { agree }\end{array} & \text { agree } & \text { disagree } & \begin{array}{l}\text { strongly } \\ \text { disagree }\end{array}\end{array}$

9. Life experiences in the black community are different from life experiences in the white community.

$\begin{array}{cccc}1 & 2 & 3 & 4 \\ \begin{array}{l}\text { strongly } \\ \text { agree }\end{array} & \text { agree } & \text { disagree } & \begin{array}{l}\text { strongly } \\ \text { disagree }\end{array}\end{array}$

10. If blacks were given equivalent opportunities in employment and education, they would achieve equality with whites.

$\begin{array}{cccc}1 & 2 & 3 & 4 \\ \text { strongly } & \text { agree } & \text { disagree } & \begin{array}{l}\text { strongly } \\ \text { agree }\end{array}\end{array}$

11. Traditional counseling methods (i.e. emphasis on intrapsychic processes rather than on external events) are effective in working with white clients.

$\begin{array}{cccc}1 & 2 & 3 & 4 \\ \begin{array}{l}\text { strongly } \\ \text { agree }\end{array} & \text { agree } & \text { disagree } & \begin{array}{l}\text { strongly } \\ \text { disagree }\end{array}\end{array}$


12. Traditional counseling methods are effective in working with black clients.

$\begin{array}{cccc}1 & 2 & 3 & 4 \\ \begin{array}{l}\text { strongly } \\ \text { agree }\end{array} & \text { agree } & \text { disagree } & \begin{array}{l}\text { strongly } \\ \text { disagree }\end{array}\end{array}$

13. The family is an example of a basic and strong unit within society.

$\begin{array}{cccc}1 & 2 & 3 & 4 \\ \begin{array}{l}\text { strongly } \\ \text { agree }\end{array} & \text { agree } & \text { disagree } & \begin{array}{l}\text { strongly } \\ \text { disagree }\end{array}\end{array}$

14. Service workers would help their clients if they involved themselves in legitimate political activities aimed at producing a more equitable society.

$\begin{array}{cccc}1 & 2 & 3 & 4 \\ \begin{array}{l}\text { strongly } \\ \text { agree }\end{array} & \text { agree } & \text { disagree } & \begin{array}{l}\text { strongly } \\ \text { disagree }\end{array}\end{array}$

15. Service workers generaliy do involve themselves in legitimate political activities aimed at producing a more equitable society.

$\begin{array}{cccc}1 & 2 & 3 & 4 \\ \text { strongly } & \text { agree } & \text { disagree } & \begin{array}{l}\text { strongly } \\ \text { agree }\end{array}\end{array}$

16. The black community has a general distrust of social service workers.

$\begin{array}{cccc}1 & 2 & 3 & 4 \\ \begin{array}{l}\text { strongly } \\ \text { agree }\end{array} & \text { agree } & \text { disagree } & \begin{array}{l}\text { strongly } \\ \text { disagree }\end{array}\end{array}$


17. Some further training regarding black language patterns would help me to better understand the way some blacks express themselves.

$\begin{array}{cccc}1 & 2 & 3 & 4 \\ \begin{array}{l}\text { strongly } \\ \text { agree }\end{array} & \text { agree } & \text { disagree } & \begin{array}{l}\text { strongly } \\ \text { disagree }\end{array}\end{array}$

18. Treatment modalities and interventions that I use with black clients are usually geared to help them cope with (adapt to) their life situations.

$\begin{array}{cccc}1 & 2 & 3 & 4 \\ \begin{array}{l}\text { strongly } \\ \text { agree }\end{array} & \text { agree } & \text { disagree } & \begin{array}{l}\text { strongly } \\ \text { disagree }\end{array}\end{array}$

19. The current system of social service delivery meets the needs of most black clients.

$\begin{array}{cccc}1 & 2 & 3 & 4 \\ \begin{array}{l}\text { strongly } \\ \text { agree }\end{array} & \text { agree } & \text { disagree } & \begin{array}{l}\text { strongly } \\ \text { disagree }\end{array}\end{array}$

20. Equalization of status between blacks and whites will not result unless conflict takes place.

$\begin{array}{cccc}1 & 2 & 3 & 4 \\ \begin{array}{l}\text { strongly } \\ \text { agree }\end{array} & \text { agree } & \text { disagree } & \begin{array}{l}\text { strongly } \\ \text { disagree }\end{array}\end{array}$

21. Further training regarding the values, norms, and culture of black people would facilitate my working with black clients.
1
2
3
4
strongly
agree
disagree
strongly
agree
disagree 
22. An intentional goal of white societal institutions (i.e. economic, educational, etc.) is to keep blacks oppressed.

$\begin{array}{cccc}1 & 2 & 3 & 4 \\ \begin{array}{l}\text { strongly } \\ \text { agree }\end{array} & \text { agree } & \text { disagree } & \begin{array}{l}\text { strongly } \\ \text { disagree }\end{array}\end{array}$

23. White societal institutions in this country keep blacks oppressed.

$\begin{array}{cccc}1 & 2 & 3 & 4 \\ \begin{array}{l}\text { strongly } \\ \text { agree }\end{array} & \text { agree } & \text { disagree } & \begin{array}{l}\text { strongly } \\ \text { disagree }\end{array}\end{array}$

24. The root causes of depression in both black and white clients are the same.

$\begin{array}{cccc}1 & 2 & 3 & 4 \\ \begin{array}{l}\text { strongly } \\ \text { agree }\end{array} & \text { agree } & \text { disagree } & \begin{array}{l}\text { strongly } \\ \text { disagree }\end{array}\end{array}$

25. Service workers need to understand the history of the black experience in this country in order to work effectively with black clients.

$\begin{array}{cccc}1 & 2 & 3 & 4 \\ \begin{array}{l}\text { strongly } \\ \text { agree }\end{array} & \text { agree } & \text { disagree } & \begin{array}{l}\text { strongly } \\ \text { disagree }\end{array}\end{array}$

26. If enough we11 run social service programs were put into effect, poor black families could get out of their cycle of poverty.

$\begin{array}{cccc}1 & 2 & 3 & 4 \\ \begin{array}{l}\text { strongly } \\ \text { agree }\end{array} & \text { agree } & \text { disagree } & \begin{array}{l}\text { strongly } \\ \text { disagree }\end{array}\end{array}$


27. A role of service workers in working with their black clients is to help them become acculturated to the dominant culture.

$\begin{array}{cccc}1 & 2 & 3 & 4 \\ \begin{array}{l}\text { strongly } \\ \text { agree }\end{array} & \text { agree } & \text { disagree } & \begin{array}{l}\text { strongly } \\ \text { disagree }\end{array}\end{array}$

28. New methods of treatment and intervention are needed in delivery of social services to black clients.

$\begin{array}{cccc}1 & 2 & 3 & 4 \\ \begin{array}{l}\text { strongly } \\ \text { agree }\end{array} & \text { agree } & \text { disagree } & \begin{array}{l}\text { strongly } \\ \text { disagree }\end{array}\end{array}$

29. Which areas of training (if any) related to more effective service delivery to the black client would you find most beneficial? Please list. 
APPENDIX II

INTRODUCTORY LETTER TO SERVICE WORKERS

November 6, 1977

Dear Service Worker:

The question of how to provide more efficient and effective services to clients is one that workers often ask themselves. We, too, have asked ourselves this question, especially as it applies to black clients.

We have two concerns with regard to provision of services. First, that clients receive the most effective service possible; second, that the needs of service workers be taken into consideration. The purpose of this questionnaire, then, is to pursue these two concerns especialiy as they apply to biack clients.

This questionnaire is being given to a random sample of service workers, who work in several agencies in the Albina community.

Please answer every question. Place the questionnaire in the envelope provided you, and return the sealed envelope to the receptionist at your agency before November 27st. To insure complete confidentiality do not write your name on the questionnaire.

Results will be used in preparation of a thesis which will be a partial fulfillment of requirements for a master's degree in social work from Portland State University.

If you have any questions, we will both be able to be reached at the Portland State University School of Social Work, 229-4712.

We sincerely appreciate your cooperation in this venture.

Very truiy yours,

Patricia Dickerson

Diane Whalen 


\section{APPENDIX III}

\section{TABLE VII}

INCOME LEVEL OF RESPONDENTS

\begin{tabular}{lcc}
\hline \hline Category & Frequency & Percentage \\
\hline $0-4,999$ & 0 & $0 \%$ \\
\hline $5,000-9,999$ & 4 & $13 \%$ \\
\hline $10,000-14,999$ & 13 & $42 \%$ \\
\hline $15,000-19,999$ & 7 & $23 \%$ \\
\hline 20,000 and up & 7 & $23 \%$ \\
\hline TOTAL & 37 & $107 \% *$ \\
\hline \hline
\end{tabular}

*Percentages do not add up to $100 \%$ due to rounding error. 